\title{
The HVC Microcircuit: The Synaptic Basis for Interactions between Song Motor and Vocal Plasticity Pathways
}

\author{
Richard Mooney and Jonathan F. Prather \\ Department of Neurobiology, Duke University School of Medicine, Durham, North Carolina 27710
}

Synaptic interactions between telencephalic neurons innervating descending motor or basal ganglia pathways are essential in the learning, planning, and execution of complex movements. Synaptic interactions within the songbird telencephalic nucleus HVC are implicated in motor and auditory activity associated with learned vocalizations. $\mathrm{HVC}$ contains projection neurons $(\mathrm{PNs})\left(\mathrm{HVC}_{\mathrm{RA}}\right)$ that innervate song premotor areas, other $\mathrm{PNs}\left(\mathrm{HVC}_{\mathrm{X}}\right)$ that innervate a basal ganglia pathway necessary for vocal plasticity, and interneurons $\left(\mathrm{HVC}_{\mathrm{INT}}\right)$. During singing, $\mathrm{HVC}_{\mathrm{RA}}$ fire in temporally sparse bursts, possibly because of $\mathrm{HVC}_{\mathrm{INT}}-\mathrm{HVC}_{\mathrm{RA}}$ interactions, and a corollary discharge can be detected in the basal ganglia pathway, likely because of synaptic transmission from $\mathrm{HVC}_{\mathrm{RA}}$ to $\mathrm{HVC}_{\mathrm{X}}$ cells. During song playback, local interactions, including inhibition onto $\mathrm{HVC}_{\mathrm{X}}$ cells, shape highly selective responses that distinguish $\mathrm{HVC}$ from its auditory afferents. To better understand the synaptic substrate for the motor and auditory properties of $\mathrm{HVC}$, we made intracellular recordings from pairs of HVC neurons in adult male zebra finch brain slices and used spike-triggered averages to assess synaptic connectivity. A major synaptic interaction between the PNs was a disynaptic inhibition from $\mathrm{HVC}_{\mathrm{RA}}$ to $\mathrm{HVC}_{\mathrm{X}}$, which could link song motor signals in the two outputs of $\mathrm{HVC}$ and account for some of the song playback-evoked inhibition in $\mathrm{HVC}_{\mathrm{X}}$ cells. Furthermore, single interneurons made divergent connections onto PNs of both types, and either PN type could form reciprocal connections with interneurons. In these two regards, the synaptic architecture of HVC resembles that described in some pattern-generating networks, underscoring features likely to be important to singing and song learning.

Key words: $\mathrm{HVC}$; in vitro intracellular; paired recordings; zebra finch; songbird; $\mathrm{GABA}_{\mathrm{A}}$; picrotoxin; unitary synaptic coupling

\section{Introduction}

Identifying synapses in the vertebrate telencephalon that link neurons in primary motor pathways with neurons in basal ganglia pathways is important to an understanding of motor learning, planning, and execution. Songbirds learn to sing via audition-dependent vocal plasticity (Konishi, 1965; Price, 1979), and the songbird telencephalic sensorimotor nucleus HVC contains different projection neurons (PNs) that give rise to either a premotor pathway specialized for song patterning or a basal ganglia pathway necessary for audition-dependent vocal plasticity (see Fig. 1) (Nottebohm et al., 1976, 1982; Fortune and Margoliash, 1995; Foster and Bottjer, 1998; Brainard and Doupe, 2000). These features make HVC an essential site to probe for synaptic interactions important to singing and song learning.

Neurons in HVC comprise at least three major types, including $\mathrm{PNs}\left(\mathrm{HVC}_{\mathrm{RA}}\right)$ that gives rise to a descending premotor pathway obligatory for song, other PNs $\left(\mathrm{HVC}_{\mathrm{X}}\right)$ that innervate a basal ganglia structure within an anterior forebrain pathway (AFP) essential to vocal plasticity, and interneurons $\left(\mathrm{HVC}_{\mathrm{INT}}\right.$ ) (see Fig.

Received Sept. 8, 2004; revised Jan. 7, 2005; accepted Jan. 8, 2005.

This work was supported by National Institutes of Health Grants DC02524 and F32 DC006152-01. We thank Dr. Stephen Shea for helpful comments on preliminary versions of this manuscript. We also acknowledge the technical support of David Kloetzer and Stefan Nenkov.

Correspondence should be addressed to Dr. Richard Mooney, Department of Neurobiology, Duke University School of Medicine, Durham, NC 27710. E-mail: mooney@neuro.duke.edu.

D01:10.1523/JNEUROSCI.3726-04.2005

Copyright $\odot 2005$ Society for Neuroscience $\quad$ 0270-6474/05/251952-13\$15.00/0
1) (Kirn et al., 1991; Johnson and Bottjer, 1993; Mooney, 2000). All three cell types extend axonal processes within HVC, affording the means for local synaptic processing (Katz and Gurney, 1981; Mooney, 2000). Several findings suggest that synaptic processing in HVC is extensive and likely to have important behavioral consequences, given the connections of $\mathrm{HVC}$ with premotor areas and the AFP. First, $\mathrm{HVC}_{\mathrm{RA}}$ neurons generate temporally sparse, high-frequency action potential bursts during singing (Hahnloser et al., 2002), and these bursts could propagate through the $\mathrm{HVC}_{\mathrm{RA}}$ ensemble via local excitatory connections and be terminated by local inhibitory interneurons. Second, AFP neurons display song motor activity (Hessler and Doupe, 1999), and this putative corollary discharge could arise because of coupling between premotor $\left(\mathrm{HVC}_{\mathrm{RA}}\right)$ and $\mathrm{HVC}_{\mathrm{X}}$ neurons (Troyer and Doupe, 2000). Finally, HVC neurons exhibit highly selective action potential responses to playback of the bird's own song (BOS), and certain features of these responses, including their temporal sparseness and sensitivity to specific syllable sequences, are thought to be refined by local circuit interactions in HVC (Margoliash, 1983; Margoliash and Fortune, 1992; Lewicki, 1996; Theunissen and Doupe, 1998; Mooney, 2000; Coleman and Mooney, 2004). Indeed, in vivo intracellular recordings show that BOS playback evokes distinct subthreshold responses and reciprocal firing patterns in the two PNs and that hyperpolarizing inhibition sculpts BOS-evoked firing patterns in $\mathrm{HVC}_{\mathrm{X}}$ cells, suggestive of interneuron-PN interactions (Mooney, 2000; Rosen and Mooney, 2003). 
Table 1. Frequency of cell pairs encountered in HVC

\begin{tabular}{|c|c|c|c|}
\hline Pair type & $\begin{array}{l}\text { Number of pairs } \\
\text { (percentage of total) }\end{array}$ & $\begin{array}{l}\text { Number of connected pairs } \\
\text { (percentage of pairs) } \\
\text { [percentage total pairs] }\end{array}$ & $\begin{array}{l}\text { Type of interaction (number of } \\
\text { observations) }\end{array}$ \\
\hline$H V C_{R A}-H V C_{X}$ & $46(47.9)$ & $6(13)[6.25]$ & $\begin{array}{l}H V C_{R A}-H V C_{X} I P S P(4) \\
H V C_{X}-H V C_{R A} d P S P(5) \\
H V C_{X}-H V C_{R A} I P S P(1) \\
\text { Three reciprocally connected pairs }\end{array}$ \\
\hline$H V C_{x}-H V C_{x}$ & $19(19.8)$ & $5(26.3)[5.21]$ & All unidirectional IPSPS \\
\hline$H V C_{I N T}-H V C_{X}$ & $12(12.5)$ & $3(25)[3.12]$ & $\begin{array}{l}H V C_{I N T}-H V C_{X} I P S P(2) \\
H V C_{X}-H V C_{I N T} d P S P(1) \\
\text { One reciprocally connected pair }\end{array}$ \\
\hline$H V C_{R A}-H V C_{R A}$ & $9(9.4)$ & $1(11.1)[1]$ & Unidirectional dPSP \\
\hline$H V C_{R A}-H V C_{I N T}$ & $6(6.2)$ & $2(33)[2]$ & $\begin{array}{l}H V C_{I N T}-H V C_{R A} \operatorname{IPSP}(1) \\
H V C_{I N T}-H V C_{R A} \operatorname{dPSP}(1)\end{array}$ \\
\hline$H V C_{I N T}-H V C_{I N T}$ & $4(4.2)$ & $1(25)[1]$ & Unidirectional IPSP \\
\hline Total & $96(100 \%)$ & $18(18.7)[\mathrm{NA}]$ & \\
\hline
\end{tabular}

acetate and 5\% Neurobiotin (Vector Laboratories, Burlingame, CA). In a few experiments, one of the two recording electrodes contained $5 \%$ Lucifer yellow (LY) in a $1 \mathrm{~m}$ lithium chloride solution. Cell penetration was achieved by briefly "ringing" the electrode using capacitance overcompensation, and the cell was then stabilized by passing regular hyperpolarizing current pulses through the recording electrode $(-0.5 \mathrm{nA}, 500 \mathrm{~ms}$ at $1 \mathrm{~Hz})$. Intracellular potentials were amplified with an Axoclamp 2B amplifier (Axon Instruments, Union City, CA) in bridge mode, low-pass filtered at $1-3 \mathrm{kHz}$, and digitized at $10 \mathrm{kHz}$. To make paired recordings, we first obtained a stable recording from an HVC neuron and then lowered the second recording electrode to a point typically within $\sim 50 \mu \mathrm{m}$ of the first electrode and searched for its synaptic partners. This search strategy tended to favor finding pairs in which the first

Although the motor and auditory properties of HVC hint at extensive local processing, knowledge of the synaptic interactions between identified HVC neuron types remains incomplete. This gap in understanding exists because axonal and dendritic processes from all three cell types as well as axonal processes from HVC afferents are interwoven with each other, complicating analysis of intrinsic connectivity (Nixdorf, 1989; Fortune and Margoliash, 1995; Foster and Bottjer, 1998; Mooney, 2000). We made intracellular recordings from pairs of identified HVC neurons in brain slices and calculated spike-triggered averages (STAs) (Perkel et al., 1967) to assess synaptic connections. We also antidromically stimulated $\mathrm{HVC}_{\mathrm{RA}}$ neurons and applied neurotransmitter receptor blockers to further characterize the intrinsic connectivity of HVC. We found extremely robust disynaptic feedforward inhibition from $\mathrm{HVC}_{\mathrm{RA}}$ to $\mathrm{HVC}_{\mathrm{X}}$ neurons, which may influence how HVC shapes and conveys song motor activity to the AFP and could account for the contrasting BOS-evoked responses in the different PNs. In addition, single interneurons can contact multiple PNs, and interneurons and PNs can form reciprocal connections. Similar architectural features contribute to synchronous oscillations in other pattern-generating networks (Selverston and Moulins, 1985) and have implications for the role of HVC in song patterning. Some results have been published in abstract form (Prather and Mooney, 2003).

\section{Materials and Methods}

These experiments use electrophysiological techniques that have been described extensively in previous published studies (Mooney, 1992; Livingston and Mooney, 1997; White et al., 1999; Livingston et al., 2000). Therefore, only a brief description of these techniques is provided here.

Subjects. Thirty-nine adult male zebra finches ( $>120 \mathrm{~d}$ posthatch) were used for these experiments, in accordance with a protocol approved by the Duke University Institutional Animal Care and Use Committee. Finches were raised in our breeding colony on a $14 / 10 \mathrm{~h}$ light/dark cycle.

Brain slices. After induction of inhalation anesthesia (halothane), the bird was decapitated, and the brain was removed rapidly and placed in oxygenated ice-cold artificial CSF (ACSF). Sagittal brain slices that included HVC were cut at 400-500 $\mu \mathrm{m}$ thickness and transferred to a holding chamber (room temperature) for 2-4 h. Individual slices were transferred to an interface-type chamber $\left(30^{\circ} \mathrm{C}\right.$; Medical Systems, Greenvale, NY) for intracellular recordings. The ACSF consisted of (in $\mathrm{mm}$ ) $119 \mathrm{NaCl}, 2.5 \mathrm{KCl}, 1.3 \mathrm{MgCl}_{2}, 2.5 \mathrm{CaCl}_{2}, 1 \mathrm{NaH}_{2} \mathrm{PO}_{4}, 26.2 \mathrm{NaHCO}_{3}$, and 11 glucose, equilibrated with $95 \% \mathrm{O}_{2} / 5 \% \mathrm{CO}_{2}$. Equiosmolar sucrose was substituted for $\mathrm{NaCl}$ during the tissue preparation stage.

Electrophysiological recordings. Sharp intracellular recordings were made with borosilicate glass pipettes (Sutter Instruments, Novato, CA) pulled to a final resistance of $80-200 \mathrm{M} \Omega$ when filled with $2 \mathrm{M}$ potassium cell obtained was of a type affording a more stable recording, which in our hands tended to be the $\mathrm{HVC}_{\mathrm{X}}$ cell type (Table 1) (see Results). Synaptically coupled cells usually could be identified on-line by the appearance of a hyperpolarizing or depolarizing response in one cell locked to the action potential discharge of the other cell, and also by subsequent on-line analysis of STAs (see below). Synaptically coupled cell pairs were most often encountered when the two electrode tips were in close $(\sim 50$ $\mu \mathrm{m}$ ) proximity to one another, and although a detailed count of unconnected pairs was not kept for all experiments, $\sim 10-20 \%$ of cell pairs showed evidence of unidirectional or bidirectional synaptic coupling.

Electrophysiological data acquisition and analysis. Data acquisition and analysis for single and paired intracellular recordings were performed using a data acquisition board (AT-MIO-16E2; National Instruments, Austin, TX), controlled by custom Labview software developed by Fred Livingston, Rob Neummann, and Merri Rosen (Duke University, Durham, NC). In paired recordings, one or two action potentials were elicited in turn from each neuron in the pair by passing brief $(\sim 10 \mathrm{~ms})$ depolarizing current pulses $(+0.5$ to $1 \mathrm{nA})$ through the recording electrode. A software threshold peak detector was used to generate STAs of the membrane potential of the partner cell in the pair. In most cases, current amplitudes and/or the resting membrane potential of the trigger cell were adjusted to elicit only a single action potential per pulse, but in a few cells, two or three spikes were sometimes evoked. In these cases, the STA was calculated off the first spike in the series. STAs were plotted in reference to the time of the trigger spike; note that the zero time for the STA corresponds to the action potential peak and that we suspect that the resultant STAs might be slightly leftward-shifted with respect to the actual onset of transmitter release (see Fig. 5B). After collecting 10-40 pulse trials per cell, we then conducted further characterizations of the impaled cells, including their responses to more prolonged depolarizing currents $(0.5 \mathrm{~s}$ at $+0.5 \mathrm{nA})$. All HVC neurons in this study were identified to type based on their DC-evoked properties, as described previously (Dutar et al., 1998; Mooney, 2000). Briefly, $\mathrm{HVC}_{\mathrm{RA}}$ neurons fire only one to several action potentials to $+0.5 \mathrm{nA}$ currents of $0.5 \mathrm{~s}$ duration, whereas $\mathrm{HVC}_{\mathrm{X}}$ neurons fire more regularly with moderate spike-frequency adaptation, and $\mathrm{HVC}_{\mathrm{INT}}$ fire at high frequency with little or no spikefrequency adaptation (see Fig. $1 D$ ). In addition, $\mathrm{HVC}_{\mathrm{INT}}$ can be distinguished from HVC PNs by their narrower spike widths ( $\sim 1$ vs $2 \mathrm{~ms}$ ) (Mooney, 2000; Rauske et al., 2003). In many cases, at least one cell in the pair was confirmed to morphological type through intracellular staining and post hoc morphological visualization. Relatively brief recording times $(<15 \mathrm{~min})$ prevented thorough filling of both cells in the recorded pair in all but a few cases.

In a subset of paired recordings from synaptically coupled cells, and in all cases in which we recorded from either a single cell or unconnected pairs for pharmacological experiments (see below), we also antidromically activated $\mathrm{HVC}_{\mathrm{RA}}$ neurons, and thus their axon collaterals within HVC, by passing currents $(\sim 25-100 \mu \mathrm{A}$ for $100 \mu \mathrm{sec})$ from an Isolator-10 stimulus isolation unit (Axon Instruments) to the HVC fibers 
that project to the robust nucleus of arcopallium (RA), using a concentric bipolar stimulating electrode (FHC, Brunswick, ME) placed midway between HVC and RA in the region of the caudal telencephalon. HVC axons innervating RA are clearly visible in the brain slice under epiillumination, appearing as large braids of whitish fibers (see Fig. $1 A$ ). Anatomical studies suggest that these fiber braids are composed exclusively of $\mathrm{HVC}_{\mathrm{RA}}$ axons, although a few $\mathrm{HVC}_{\mathrm{X}}$ axons do travel medial to this area but outside the plane of the slices used here (Mooney, 2000). This mid-point placement was chosen because it is unlikely to activate axons of $\mathrm{HVC}$ afferents. Furthermore, antidromic activation of $\mathrm{HVC}_{\mathrm{RA}}$ neurons was confirmed in some recordings by the appearance of an action potential riding on the shoulder of the stimulus artifact itself. In contrast, as $\mathrm{HVC}_{\mathrm{X}}$ axons exit rostrally and ventrally from the nucleus, they intermingle with axons arising from several afferents of HVC (i.e., NIf, Uva, and mMAN). This organization renders selective recruitment of $\mathrm{HVC}_{\mathrm{X}}$ axon collaterals by extracellular stimulation in the brain slice unlikely, and thus we did not attempt to use an antidromic stimulation approach to activate $\mathrm{HVC}_{\mathrm{X}}$ axon collaterals. Instead, we relied solely on paired recordings to deduce the nature of the synaptic connectivity that $\mathrm{HVC}_{\mathrm{X}}$ neurons make with the other HVC neuron types.

Several different features of the STA were characterized off-line, including the peak amplitude, the time to peak, and the $25 \%$ rise time (i.e., the time to reach $25 \%$ of the peak amplitude). In the small minority of cases in which the trigger neuron spiked repetitively and the STA demonstrated a biphasic peak, the first peak was used for these measurements. An ANOVA was used to compare a given STA feature across different cell pair types, followed by Tukey's post hoc test corrected for multiple comparisons. Values reported are the mean \pm SEM, unless noted otherwise.

Synaptic pharmacology. To analyze the types of postsynaptic receptors activated either after antidromic stimulation of $\mathrm{HVC}_{\mathrm{RA}}$ neurons or in the case of some synaptically coupled pairs, drugs were bath applied to the whole slice after collecting evoked synaptic responses for a 5-10 min baseline period. Picrotoxin (PTX; $50 \mu \mathrm{M}$ ) was used to block inhibitory receptors of the $\mathrm{GABA}_{\mathrm{A}}$ subtype, whereas $\mathrm{D}(-)$-2-amino-5-phophonopentanoic acid (D-APV; $50 \mu \mathrm{M}$ ) was used to block excitatory transmission mediated by NMDA receptors and 1,2,3,4-tetrahydro-6-nitro-2,3dioxo-benzo $(f)$ quinoxaline-7-sulfonamide disodium (NBQX; $10 \mu \mathrm{M}$ ) was used to block fast excitatory transmission mediated by ionotropic glutamate receptors of the AMPA subtype. The use of an interface chamber, which we prefer for its superior slice viability compared with submersion chambers, especially when recording above room temperature, precluded collecting washouts in most cases (i.e., washout times greatly exceeded $1 \mathrm{~h}$ ). We used other features, such as the maintenance of excitatory transmission in the presence of PTX, as well as resting membrane potential and input impedance, to determine that synaptic blockade did not reflect a general rundown of the cell or the slice. Drug effects were assessed using paired or unpaired $t$ tests, as appropriate for normally distributed data, and a Mann-Whiney $U$ test for other data sets.

Intracellular staining and imaging. After acquiring electrophysiological data, Neurobiotin was iontophoresed into the cell with positive current pulses ( +0.5 to $1 \mathrm{nA}, 500 \mathrm{~ms}$ per second, for $\sim 15 \mathrm{~min}$ ). For LY staining, negative current pulses were passed through the electrode $(-1 \mathrm{nA}, 500$ $\mathrm{ms}$ at $1 \mathrm{~Hz}$ ). Slices then were fixed in $4 \%$ paraformaldehyde in $25 \mathrm{~mm}$ sodium phosphate buffer (PB) overnight at $4^{\circ} \mathrm{C}$ and then sunk in $30 \%$ sucrose in $25 \mathrm{~mm}$ PB. Slices then were resectioned at $75-100 \mu \mathrm{m}$ thickness on a freezing microtome, and Neurobiotin was visualized with a standard avidin-fluorophore reaction using a 1:1000 dilution of avidinAlexa Fluor 488 or 564 (Molecular Probes, Eugene, OR). Confocal images were generated with a Zeiss (Thornwood, NY) 510 laser scanning microscope, using either a $40 \times[1.3$ numerical aperture $(\mathrm{NA})]$ or $63 \times$ (1.4 NA) Zeiss NeoFluar objective and rhodamine/fluorescein filters [488 and $543 \mathrm{~nm}$ excitation wavelengths, emission bandpass filter of $500-540 \mathrm{~nm}$, and emission long-pass filter of 560, sampled in an alternating frame arrangement; optical sections of 1 Airey unit $(\sim 1 \mu \mathrm{m}$ thickness), with Kalman averaging $=2]$.

Parvalbumin immunoreactivity. In some experiments, we combined intracellular staining with Neurobiotin and immunohistochemical methods to determine which cells in HVC were positive for parvalbumin
(PV), a calcium-binding protein previously localized to HVC interneurons (Wild et al., 2005). After cell fills, brain slices were transferred to $4 \%$ paraformaldehyde within $30 \mathrm{~min}$, where they remained for a minimum of $24 \mathrm{~h}$ before being placed in 30\% sucrose for several hours and then sectioned at $50 \mu \mathrm{m}$ on a freezing microtome. The sections were then incubated in streptavidin-Alexa Fluor 488 in PBS-Triton X-100 overnight, washed in PBS, and incubated overnight again with anti-PV antibody (mouse monoclonal; Swant, Bellinzona, Switzerland) at a dilution of 1:500. All immunohistochemical reactions were performed on free-floating sections at room temperature in PBS containing 0.4\% Triton X-100 (PBS-TX). Primary antibody incubations were performed overnight with the inclusion of $2.5 \%$ normal horse serum and $0.1 \%$ sodium azide. PV was visualized using a biotinylated horse anti-mouse antibody (Vector Laboratories), followed by streptavidin-Alexa Fluor 564 (Molecular Probes). Secondary antibody incubations were $1-2 \mathrm{~h}$ in duration in PBS-TX. Between treatments, the sections were washed thoroughly in PBS.

\section{Results}

We used blind dual sharp microelectrode recording techniques to record from synaptically coupled pairs of cells in the telencephalic song nucleus HVC (Fig. 1A,B). Previous in vitro and in vivo studies have shown that in addition to their morphological differences, $\mathrm{HVC}_{\mathrm{RA}}, \mathrm{HVC}_{\mathrm{X}}$, and $\mathrm{HVC}_{\mathrm{INT}}$ are readily distinguished from each other based on their DC-evoked firing properties (Dutar et al., 1998; Mooney, 2000). In the present study, we identified all cells by their DC-evoked action potential responses and/or intracellular staining with Neurobiotin and post hoc visualization (Fig. 1C,D) (see Materials and Methods). Synaptic potentials were evident as depolarizing or hyperpolarizing membrane potential responses in one of the cells immediately after the spontaneous and/or DC-evoked action potentials of the other cell. With respect to both raw and averaged membrane potential records, we refer to spike-evoked responses that are hyperpolarizing as IPSPs, depolarizing responses as dPSPs, and depolarizing responses that demonstrably evoked spiking in the postsynaptic cell as EPSPs. In all cases, action potentials were evoked in turn from each of the cells in the pair, allowing us to assess synaptic coupling in both directions. In total, we found 79 neuron pairs that exhibited evidence of either unidirectional or bidirectional synaptic coupling, including $29 \mathrm{HVC}_{\mathrm{RA}}-\mathrm{HVC}_{\mathrm{X}}$ pairs, 20 $\mathrm{HVC}_{\mathrm{INT}}-\mathrm{HVC}_{\mathrm{X}}$ pairs, $13 \mathrm{HVC}_{\mathrm{RA}}-\mathrm{HVC}_{\mathrm{INT}}$ pairs, $11 \mathrm{HVC}_{\mathrm{X}}-\mathrm{H}-$ $\mathrm{VC}_{\mathrm{X}}$ pairs, $5 \mathrm{HVC}_{\mathrm{RA}}-\mathrm{HVC}_{\mathrm{RA}}$ pairs, and $1 \mathrm{HVC}_{\mathrm{INT}}-\mathrm{HVC}_{\mathrm{INT}}$ pair ( $n=53$ slices from 30 birds). In this study, the relative abundance of connected neuronal pairs of a given class is dependent on both the true probability of connections within that class and the probability of sampling from that class. Therefore, the major focus of these results is on describing the nature of connections in each class of paired cells rather than the relative prevalence of connections among the different classes.

\section{$\mathrm{HVC}_{\mathrm{RA}}-\mathrm{HVC}_{\mathrm{X}}$ pairs}

A total of $29 \mathrm{HVC}_{\mathrm{X}}-\mathrm{HVC}_{\mathrm{RA}}$ neuronal pairs exhibited evidence of synaptic coupling. In almost all (26 of 29) pairs of synaptically coupled $\mathrm{HVC}_{\mathrm{RA}}-\mathrm{HVC}_{\mathrm{X}}$ neurons, DC-evoked action potentials in the $\mathrm{HVC}_{\mathrm{RA}}$ neuron triggered a synaptic response in the $\mathrm{HVC}_{\mathrm{X}}$ neuron. In the vast majority of these cases, action potentials in the $\mathrm{HVC}_{\mathrm{RA}}$ neuron evoked an IPSP in the $\mathrm{HVC}_{\mathrm{X}}$ cell (Fig. $2 \mathrm{~A}$, Table 2) (25 of 26 cases evoked IPSPs; 1 of 26 cases evoked a dPSP). The amplitudes of these $\mathrm{HVC}_{\mathrm{RA}}-\mathrm{HVC}_{\mathrm{X}}$ IPSPs often were sufficiently large $(>1 \mathrm{mV})$ to be visible without averaging. $\mathrm{HVC}_{\mathrm{RA}}$ STAs (see Materials and Methods) of the $\mathrm{HVC}_{\mathrm{X}}$ neuronal membrane potential had an average peak amplitude of $-1.5 \pm 0.3 \mathrm{mV}$, an average time to peak of $15.7 \pm 1.0 \mathrm{~ms}$, and a $25 \%$ rise time of $4.8 \pm 0.4 \mathrm{~ms}(n=25)$ (Fig. $2 B$, Table 2$)$. 


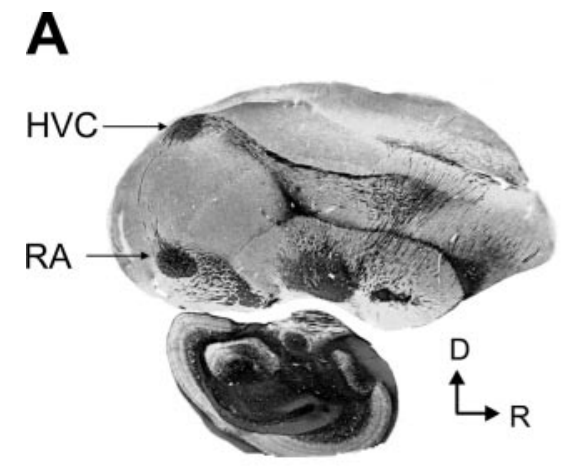

\section{B}
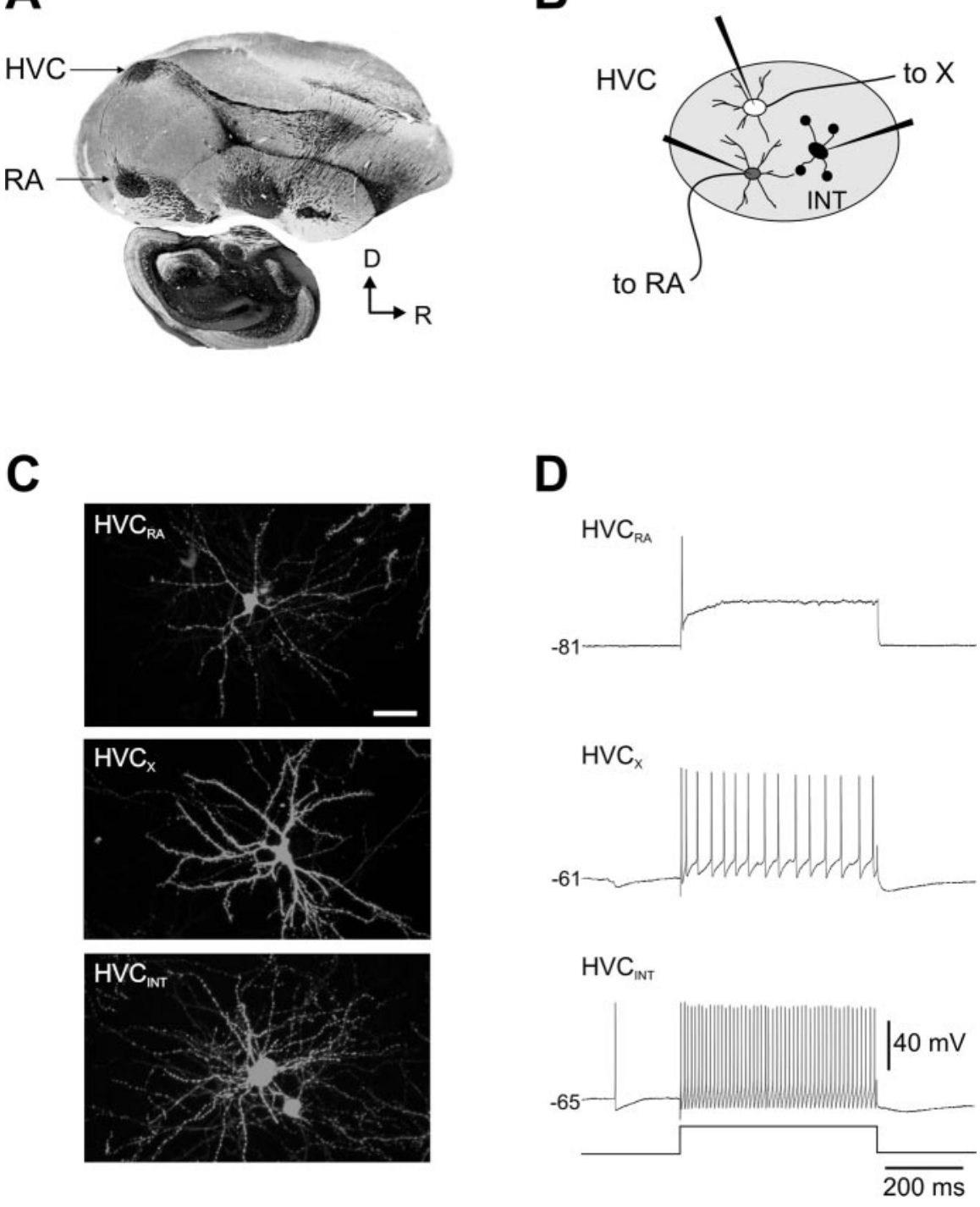

Figure 1. The song nucleus HVC in the zebra finch telencephalon contains two different classes of PN and at least one class of interneurons. $A$, A sagittal section through the telencephalon of an adult male zebra finch, stained for myelin, showing the song nucleus HVC and one of its two efferent targets, the song premotor nucleus RA. HVC fibers transiting to RA can be seen between the two nuclei. Area X, the other efferent target of HVC, is medial to this plane of section. D, Dorsal; $R$, rostral. $B$, A schematic of the song nucleus HVC, showing the three neuron classes, including PNs that innervate RA $\left(H V C_{R A}\right)$, PNs that innervate Area $X\left(H V C_{x}\right)$, and interneurons. Simultaneous dual electrode recordings were made from different pairs of HVC neurons to study their synaptic connectivity. C, Confocal images of the three HVC neuron types studied here, as revealed by intracellular staining with Neurobiotin and post hoc visualization with avidin-Alexa Fluor 488 (see Materials and Methods). $\mathrm{HVC}_{\mathrm{RA}}$ neurons (top) possessed slender and sparsely spinous dendrites and elaborated a main axon that exited at the caudal margin of HVC. $H V C_{x}$ neurons (middle) were characterized by thicker and more spinous dendrites and an axon that exited HVC along its rostroventral border. Interneurons (bottom) were characterized by aspinous, varicose dendrites and lacked an axon that exited HVC. Scale bar, $20 \mu \mathrm{m}$. D, Typical membrane potential responses of the three HVC neuron types to depolarizing current pulses (bottom trace). $\mathrm{HVC}_{\mathrm{RA}}$ neurons (top trace) fired only one or a few action potentials, even in response to large-amplitude depolarizing currents $(+1.5 \mathrm{nA})$. $\mathrm{HVC}_{\mathrm{X}}$ neurons (middle trace) fired repetitively to moderate currents $(+0.5 \mathrm{nA})$ with some spike-frequency accommodation. Interneurons ( $\left.\mathrm{HVC}_{\mathrm{INT}}\right)$ fired at high frequencies with little or no spike-frequency accommodation in response to moderate depolarizing current $(+0.5 \mathrm{nA})$. Action potential widths of interneurons are narrower than in either of the PN types (data not shown). Resting potentials (in millivolts) are shown to the left of each membrane potential trace.

Synaptic coupling from $\mathrm{HVC}_{\mathrm{X}}$ to $\mathrm{HVC}_{\mathrm{RA}}$ neurons was detected less frequently. In 7 of 29 pairs of synaptically coupled $\mathrm{HVC}_{\mathrm{RA}}-\mathrm{HVC}_{\mathrm{X}}$ neurons, action potentials in the $\mathrm{HVC}_{\mathrm{X}}$ cell triggered synaptic responses in $\mathrm{HVC}_{\mathrm{RA}}$ neurons. In four of these cases, action potentials in the $\mathrm{HVC}_{\mathrm{X}}$ neuron evoked a dPSP in the $\mathrm{HVC}_{\mathrm{RA}}$ cell, whereas in the other three cases, IPSPs were elicited (Table 2). Notably, reciprocal connections were detected in 5 of the 29 pairs of synaptically coupled HV$\mathrm{C}_{\mathrm{RA}}-\mathrm{HVC}_{\mathrm{X}}$ neurons (data not shown). In all of these cases, action potentials in the $\mathrm{HVC}_{\mathrm{RA}}$ neuron evoked IPSPs in the $\mathrm{HVC}_{\mathrm{X}}$ cell; $\mathrm{HVC}_{\mathrm{X}}$ cell action potentials evoked dEPSPs in three of these pairs and IPSPs in the other two pairs. These results indicate that bidirectional synaptic interactions, including reciprocal inhibitory interactions, can occur between $\mathrm{HVC}_{\mathrm{RA}}$ and $\mathrm{HVC}_{\mathrm{X}}$ neurons. Furthermore, these recordings suggest that a dominant pattern of synaptic connectivity between the two HVC PNs involves inhibition from HV$\mathrm{C}_{\mathrm{RA}}$ to $\mathrm{HVC}_{\mathrm{X}}$ neurons.

We suspected that the inhibitory interaction between $\mathrm{HVC}_{\mathrm{RA}}$ and $\mathrm{HVC}_{\mathrm{X}}$ neurons was mediated by interposed interneurons, given that $\mathrm{HVC}_{\mathrm{RA}}$ neurons are known to evoke ionotropic glutamate receptor-mediated EPSPs in neurons in the song nucleus RA (Mooney and Konishi, 1991). In this model, the local collaterals of $\mathrm{HVC}_{\mathrm{RA}}$ neurons excite inhibitory interneurons via ionotropic glutamatergic synapses, which in turn make inhibitory synapses on $\mathrm{HVC}_{\mathrm{X}}$ neurons. Consistent with the disynaptic model, both the mean $25 \%$ rise time and the mean time to peak of IPSPs in $\mathrm{HVC}_{\mathrm{RA}}-\mathrm{HVC}_{\mathrm{X}}$ cell pairs were significantly longer than those of the IPSPs evoked in $\mathrm{HVC}_{\mathrm{X}}$ cells by interneurons (see Table 2 for statistical comparisons and the following discussion of synaptic coupling in $\mathrm{HVC}_{\mathrm{INT}}-\mathrm{HVC}_{\mathrm{X}}$ cells pairs) (see also Fig. 5B). Furthermore, in some $\mathrm{HVC}_{\mathrm{RA}}-\mathrm{HVC}_{\mathrm{X}}$ cell pairs, hyperpolarizing responses in $\mathrm{HVC}_{\mathrm{X}}$ neurons only were evoked when the $\mathrm{HVC}_{\mathrm{RA}}$ neuron fired a spike doublet or triplet, possibly reflecting facilitation at an intervening excitatory synapse (Fig. $2 C$ ) ( $n=2$ cases). These observations provide indirect evidence that $\mathrm{HVC}_{\mathrm{RA}}$ cells evoke IPSPs in HVC $\mathrm{X}$ neurons via a disynaptic mechanism. Another possibility is that the axon collaterals of HV$\mathrm{C}_{\mathrm{RA}}$ neurons provide monosynaptic inhibition onto $\mathrm{HVC}_{\mathrm{X}}$ neurons, perhaps via the hyperpolarizing metabotropic glutamate receptors that have been detected within HVC (Schmidt and Perkel, 1998; Dutar et al., 1999, 2000). This monosynaptic model is less likely, given that metabotropic forms of synaptic transmission typically exhibit a much slower onset than observed here for $\mathrm{HVC}_{\mathrm{RA}}-\mathrm{HVC}_{\mathrm{X}}$ cell pairs.

These two models can be distinguished by pharmacological methods: $\mathrm{HVC}_{\mathrm{RA}}$-evoked IPSPs in $\mathrm{HVC}_{\mathrm{X}}$ neurons mediated by the disynaptic mechanism will be abolished by ionotropic glutamate receptor blockers, whereas IPSPs mediated by a monosynaptic, metabotropic glutamatergic pathway should not be affected by such treatment. To distinguish between these two outcomes, we recorded intracellularly from $\mathrm{HVC}_{\mathrm{X}}$ cells and an- 
A

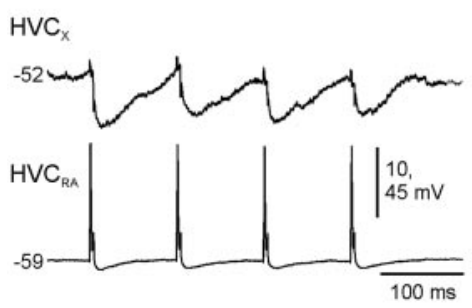

C

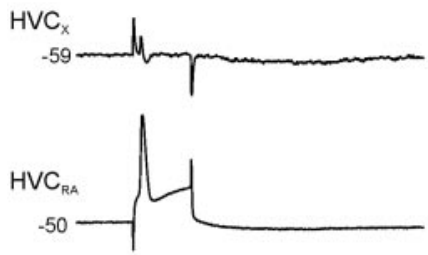

B
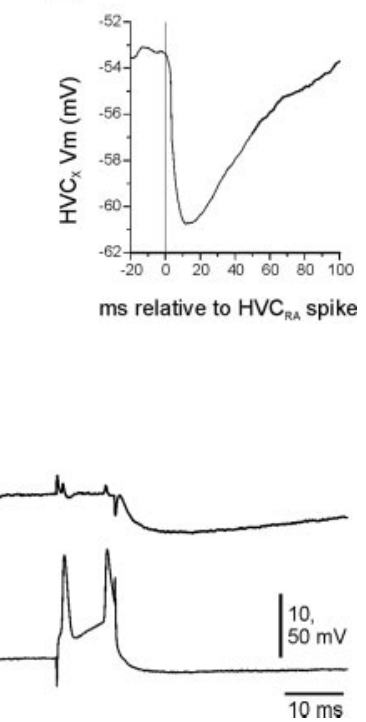

Figure 2. Action potentials in $\mathrm{HVC}_{\mathrm{RA}}$ neurons evoke IPSPs in $H V C_{x}$ neurons. $A$, Dual intracellular recordings show that $D C$-evoked action potentials in the $\mathrm{HVC}_{\mathrm{RA}}$ neuron (bottom trace) can evoke IPSPs in the $\mathrm{HVC}_{\mathrm{X}}$ neuron. $\boldsymbol{B}, \mathrm{An} \mathrm{HVC}_{\mathrm{RA}}$ STA of the $\mathrm{HVC}_{\mathrm{X}}$ neuron membrane potential, plotted relative to the $\mathrm{HVC}_{\mathrm{RA}}$ action potential peak (0 ms; positive times follow the action potential), for the cell pair shown in $A$. A membrane hyperpolarization followed the $\mathrm{HVC}_{\mathrm{RA}}$ action potential, indicating that $\mathrm{HVC}_{\mathrm{RA}}$ neurons directly or indirectly drive IPSPs in the $\mathrm{HVC}_{\mathrm{X}}$ cell. C, In some $\mathrm{HVC}_{\mathrm{RA}}-\mathrm{HVC}_{\mathrm{X}}$ cell pairs, spike doublets in the $\mathrm{HVC}_{\mathrm{RA}}$ neuron were necessary to drive IPSPs in the $\mathrm{HVC}_{X}$ cell (right traces), whereas single spikes failed to evoke any response (left traces), suggestive of disynaptic coupling.

tidromically activated $\mathrm{HVC}_{\mathrm{RA}}$ axon collaterals en masse and then bath applied ionotropic glutamate receptor blockers to the slice (Fig. 3). In control conditions, antidromic stimulation of $\mathrm{HVC}_{\mathrm{RA}}$ axons evoked robust IPSPs in all $\mathrm{HVC}_{\mathrm{X}}$ neurons that we tested $(n=5)$, and in all cases, these IPSPs were abolished by the bath application of a mixture of ionotropic glutamate receptor blockers, NBQX $(10 \mu \mathrm{M})$ and D-APV $(50 \mu \mathrm{M})$ (Fig. 3) (mean \pm SD: control, $-12.4 \pm 4.8 \mathrm{mV}$; drug, $0.9 \pm 1.7 \mathrm{mV}$; paired $t$ test; $n=$ $5 ; p=0.00132$ ). These results support a model in which $\mathrm{HVC}_{\mathrm{RA}}$ axon collaterals activate excitatory ionotropic glutamate receptors on inhibitory interneurons, ultimately providing a disynaptic inhibitory linkage from $\mathrm{HVC}_{\mathrm{RA}}$ to $\mathrm{HVC}_{\mathrm{X}}$ cells. Together with the results of paired recordings, these experiments also suggest that the $\mathrm{HVC}_{\mathrm{RA}}$-interneuron excitatory coupling is sufficiently robust to enable single $\mathrm{HVC}_{\mathrm{RA}}$ neurons to drive disynaptic, feedforward inhibition in $\mathrm{HVC}_{\mathrm{X}}$ neurons.

\section{$\mathrm{HVC}_{\mathrm{RA}}-\mathrm{HVC}_{\mathrm{INT}}$ pairs}

Paired recordings provided direct evidence of the excitatory nature of the synaptic contacts that $\mathrm{HVC}_{\mathrm{RA}}$ axon collaterals make onto $\mathrm{HVC}_{\mathrm{INT}}$, consistent with the disynaptic model of feedforward inhibition between $\mathrm{HVC}_{\mathrm{RA}}$ and $\mathrm{HVC}_{\mathrm{X}}$ cells (Fig. $4 A$ ). A total of $13 \mathrm{HVC}_{\mathrm{RA}}-\mathrm{HVC}_{\mathrm{INT}}$ cell pairs revealed evidence of unidirectional or bidirectional synaptic coupling. Seven cases of $\mathrm{HVC}_{\mathrm{RA}}$-to-HVC $\mathrm{HNT}_{\mathrm{INT}}$ coupling were observed, and in six of those cases, DCevoked action potentials in the $\mathrm{HVC}_{\mathrm{RA}}$ neuron evoked a fast dPSP in the corre-

sponding $\mathrm{HVC}_{\mathrm{INT}}$ (six of seven $\mathrm{HVC}_{\mathrm{RA}}$ neurons evoked positive STAs in the interneuron; one of seven $\mathrm{HVC}_{\mathrm{RA}}$ neurons evoked an IPSP). These dPSPs were characterized by a rapid time course and often by their large amplitudes (Fig. $4 B$, Table 2) (average peak amplitude, $2.0 \pm 0.4 \mathrm{mV}$; average time to peak, $4.7 \pm 0.5 \mathrm{~ms} ; 25 \%$ rise time, $1.4 \pm 0.1 \mathrm{~ms} ; n=6)$. The strength and excitatory nature of this connection was reflected in the observation that a single spike in the $\mathrm{HVC}_{\mathrm{RA}}$ neuron often was sufficient to drive the interneuron to spike threshold (Fig. $4 A, C$ ) (five of six $\mathrm{HVC}_{\mathrm{RA}^{-}}$ $\mathrm{HVC}_{\mathrm{INT}}$ pairs displayed such one-for-one spike coupling). This one-to-one spike coupling could account for how a single action potential in an $\mathrm{HVC}_{\mathrm{RA}}$ neuron can evoke an IPSP in an $\mathrm{HVC}_{\mathrm{X}}$ neuron. Furthermore, we noted that spike doublets or triplets in the $\mathrm{HVC}_{\mathrm{RA}}$ neuron could trigger facilitation of EPSPs in the $\mathrm{HVC}_{\mathrm{INT}}$ (Fig. $\left.4 C\right)$ ( $n=2$ pairs). On average, PSPs corresponding to doublet or triplet spikes were facilitated by $46 \%$ (paired $t$ test; $p<0.01$ ), measured at an average inter-PSP interval of $27 \mathrm{~ms}$. Such facilitation may explain the observation that spike doublets in $\mathrm{HVC}_{\mathrm{RA}}$ neurons sometimes were required to trigger IPSPs in $\mathrm{HVC}_{\mathrm{X}}$ cells. In summary, $\mathrm{HVC}_{\mathrm{RA}}$ neurons provide short-latency excitatory synaptic input to interneurons.

Paired recordings also revealed that interneurons could make synaptic contacts on $\mathrm{HVC}_{\mathrm{RA}}$ neurons. Eight of the 13 coupled $\mathrm{HVC}_{\mathrm{RA}}-\mathrm{HVC}_{\mathrm{INT}}$ pairs showed evidence of synaptic transmission from the interneuron to the PN. In six pairs, the interneuron action potential evoked an IPSP in the $\mathrm{HVC}_{\mathrm{RA}}$ neuron (individual data not shown; average peak amplitude, $-0.9 \pm 0.2 \mathrm{mV}$; average time to peak, $10.7 \pm 2.3 \mathrm{~ms} ; 25 \%$ rise time, $1.7 \pm 1.0 \mathrm{~ms}$; $n=6$ ) (for mean data, see Table 2), whereas in two pairs, the interneuron action potential evoked a dPSP in the $\mathrm{HVC}_{\mathrm{RA}}$ cell (data not shown). The mean $25 \%$ rise time and the mean time to peak of these interneuron-evoked IPSPs were not significantly longer than those recorded in $\mathrm{HVC}_{\mathrm{INT}}-\mathrm{HVC}_{\mathrm{X}}$ pairs, consistent with the idea that they were attributable to monosynaptic connections (for statistical comparisons, see Table 2). These results indicate that the $\mathrm{HVC}_{\mathrm{RA}}-\mathrm{HVC}_{\mathrm{INT}}$ coupling is robust and bidirectional, at least at the population level. Notably, reciprocal connections were detected in two $\mathrm{HVC}_{\mathrm{RA}}-\mathrm{HVC}_{\mathrm{INT}}$ pairs (data not shown). In both cases, the interneuron to PN interaction was inhibitory, whereas the PN to interneuron coupling was excitatory in one case and inhibitory in the other. The latter case may reflect a disynaptic pathway, because the PN-interneuron STA was of longer latency than the interneuron-PN STA (data not shown). The strong excitatory coupling from $\mathrm{HVC}_{\mathrm{RA}}$ to $\mathrm{HVC}_{\mathrm{INT}}$

\section{Table 2. Characteristics of synaptic responses in connected HVC neuron pairs}

\begin{tabular}{|c|c|c|c|}
\hline $\begin{array}{l}\text { Pair type (number of pairs with given PSP/ } \\
\text { total number of connected pairs of given type) }\end{array}$ & Peak amplitude (mV) & Time to peak (ms) & $25 \%$ rise time (ms) \\
\hline \multicolumn{4}{|l|}{ IPSPS } \\
\hline$H V C_{R A}>H V C_{X}(25$ of 29$)$ & $-1.5 \pm 0.3$ & $15.7 \pm 1.0$ & $4.8 \pm 0.4$ \\
\hline$H V C_{X}>H V C_{R A}(3$ of 29$)$ & $-1.1 \pm 0.1$ & $9.9 \pm 1.3$ & $2.6 \pm 0.7$ \\
\hline$H V C_{X}>H V C_{X}(11$ of 11$)$ & $-2.0 \pm 0.4$ & $15.4 \pm 2.7$ & $5.0 \pm 1.7$ \\
\hline $\mathrm{HVC}_{\mathrm{INT}}>\mathrm{HVC}_{\mathrm{X}}(19$ of 20$)$ & $-1.2 \pm 0.2$ & $10.2 \pm 0.9^{a}$ & $1.4 \pm 0.3^{b}$ \\
\hline $\mathrm{HVC}_{\mathrm{INT}}>\mathrm{HVC}_{\mathrm{RA}}(6$ of 13$)$ & $-0.9 \pm 0.2$ & $10.7 \pm 2.3^{c}$ & $1.7 \pm 1.0^{c}$ \\
\hline \multicolumn{4}{|l|}{ dPSPS } \\
\hline$H V C_{R A}>H^{\prime} C_{I N T}(6$ of 13$)$ & $2.0 \pm 0.4$ & $4.7 \pm 0.5$ & $1.4 \pm 0.1$ \\
\hline $\mathrm{HVC}_{\mathrm{X}}>\mathrm{HVC}_{\mathrm{INT}}(5$ of 20$)$ & $1.2 \pm 0.3$ & $4.3 \pm 0.4^{d}$ & $1.0 \pm 0.6^{d}$ \\
\hline$H V C_{R A}>H^{\prime} C_{R A}(4$ of 4$)$ & $2.2 \pm 1.1$ & $9.1 \pm 2.3$ & $4.0 \pm 0.3$ \\
\hline $\mathrm{HVC}_{\mathrm{X}}>\mathrm{HVC}_{\mathrm{RA}}(4$ of 29$)$ & $0.5 \pm 0.1$ & $8.3 \pm 0.9$ & $3.2 \pm 0.3$ \\
\hline \multicolumn{4}{|l|}{$a_{p}<0.05$ versus $\mathrm{HVC}_{\mathrm{RA}}>\mathrm{HVC}_{\mathrm{X}}$, by ANOVA. } \\
\hline \multicolumn{4}{|l|}{${ }^{b} p<0.05$ versus $\mathrm{HVC}_{\mathrm{RA}}>\mathrm{HVC}_{\mathrm{X}}$ and $\mathrm{HVC}_{\mathrm{X}}>\mathrm{HVC}_{\mathrm{X}}$, by ANOVA. } \\
\hline \multicolumn{4}{|l|}{$c_{p}>0.05$ versus HVC $\mathrm{CNT}_{\mathrm{INT}}>\mathrm{HVC}_{x}$, by ANOVA. } \\
\hline${ }^{d} p>0.05$ versus $\mathrm{HVC}_{\mathrm{RA}}>\mathrm{HVC}_{\mathrm{IN}}$, by unpaired $t$ test. & & & \\
\hline
\end{tabular}



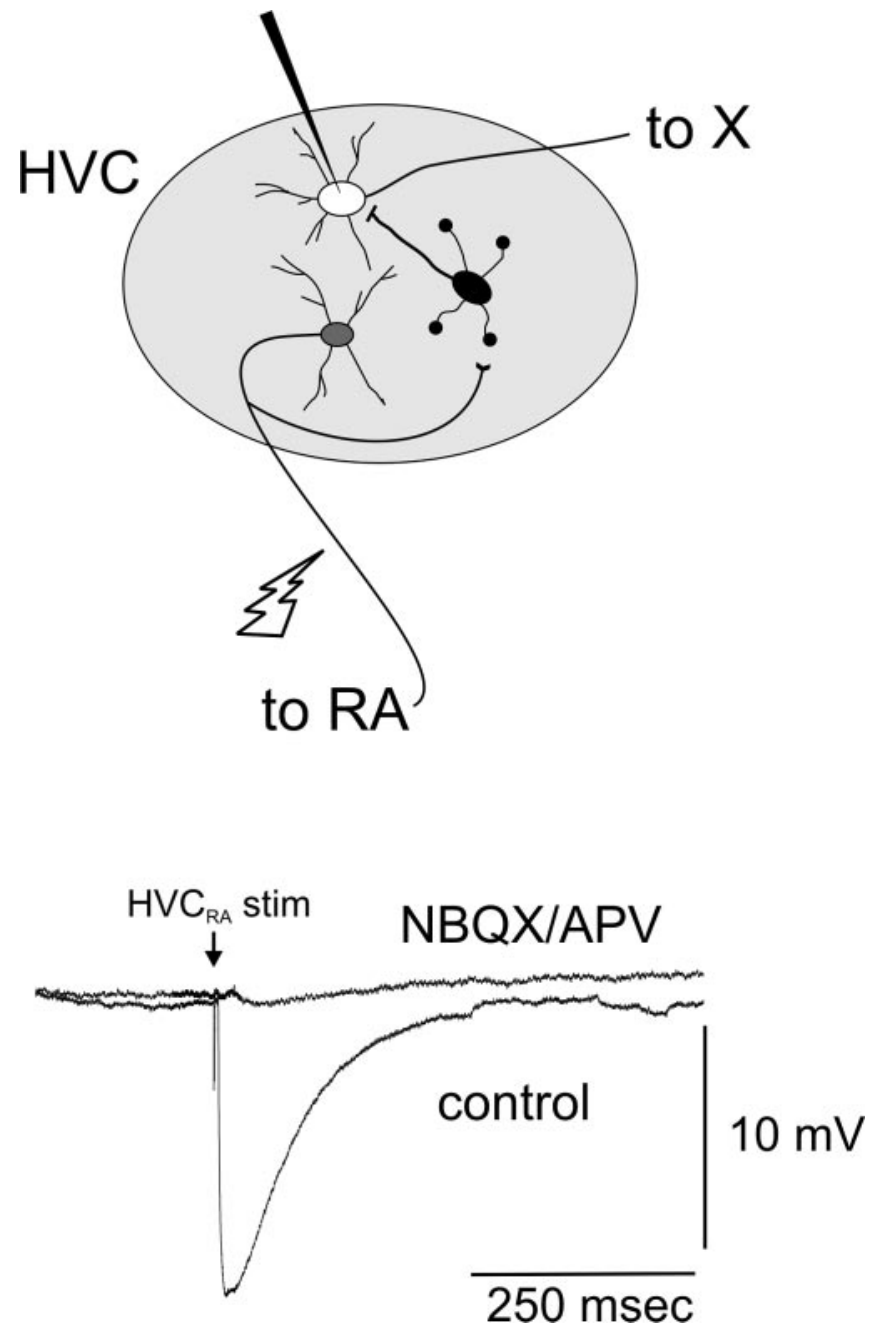

Figure 3. Antidromic stimulation of $\mathrm{HVC}_{\mathrm{RA}}$ axons can be used to characterize the pharmacological nature of the inhibitory interactions between $H V C_{R A}$ and $H V C_{X}$ cells. A schematic of the slice preparation (top), showing how antidromic stimulation of the $\mathrm{HVC}_{\mathrm{RA}}$ axon fiber bundle (lightning bolt) can be used to activate the HVC microcircuit while recording intracellularly from $H V C_{X}$ cells. In this model, local collaterals of the $\mathrm{HVC}_{\mathrm{RA}}$ axon excite $\mathrm{HVC}_{\mathrm{INT}}$, which ultimately drive IPSPs in the $H V C_{X}$ cell. Consistent with this idea, electrical stimulation of the $H V C_{R A}$ fibers

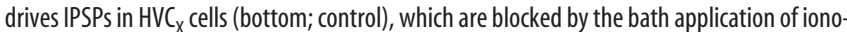
tropic glutamate receptor antagonists (NBQX/APV).

and the existence of reciprocal inhibitory connections from $\mathrm{HVC}_{\mathrm{INT}}$ to $\mathrm{HVC}_{\mathrm{RA}}$ suggests that action potential activity in $\mathrm{HV}$ $\mathrm{C}_{\mathrm{RA}}$ neurons could be shaped by inhibitory feedback acting on a spike-by-spike basis.

\section{HVC $_{\text {INT }}-\mathrm{HVC}_{\mathrm{X}}$ pairs}

Paired recordings also revealed that interneurons could provide inhibitory input to $\mathrm{HVC}_{\mathrm{X}}$ cells. In almost all synaptically connected $\mathrm{HVC}_{\mathrm{INT}}-\mathrm{HVC}_{\mathrm{X}}$ cell pairs, an action potential in the interneuron evoked an IPSP in the $\mathrm{HVC}_{\mathrm{X}}$ cell (Fig. 5A) (19 of 20 cases; average peak amplitude, $-1.2 \pm 0.2 \mathrm{mV}$; average time to peak, $10.2 \pm 0.9 \mathrm{~ms} ; 25 \%$ rise time, $1.4 \pm 0.3 \mathrm{~ms} ; n=19$ ) (Table 2). In one case, unidirectional coupling from the $\mathrm{HVC}_{\mathrm{X}}$ neuron to the interneuron, in the form of a dPSP, was observed (data not shown). We noted that interneuron-evoked IPSPs in $\mathrm{HVC}_{\mathrm{X}}$ cells had faster rise times and times to peak than did IPSPs recorded in $\mathrm{HVC}_{\mathrm{RA}}-\mathrm{HVC}_{\mathrm{X}}$ cell pairs, although IPSPs of either type otherwise had a similar overall shape and time course (Fig. 5B) (for statistical comparisons, see Table 2). The very short onset latency of

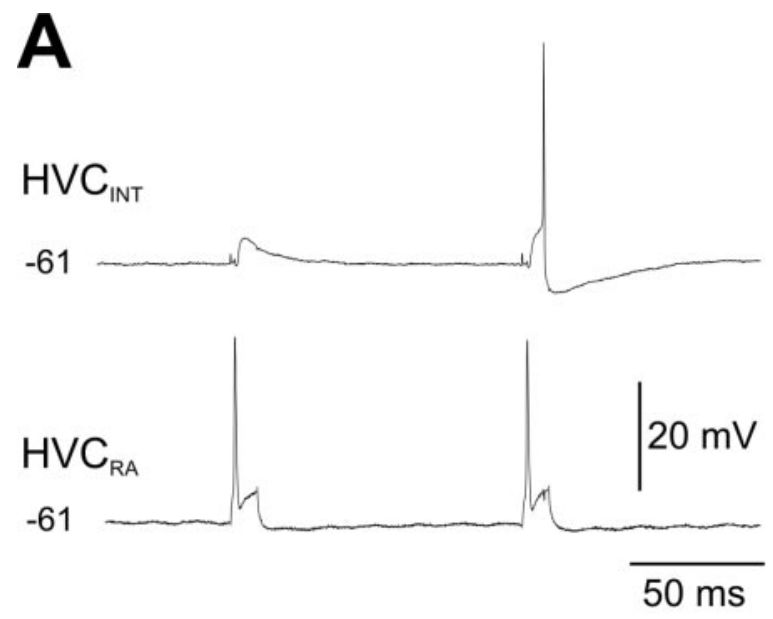

B
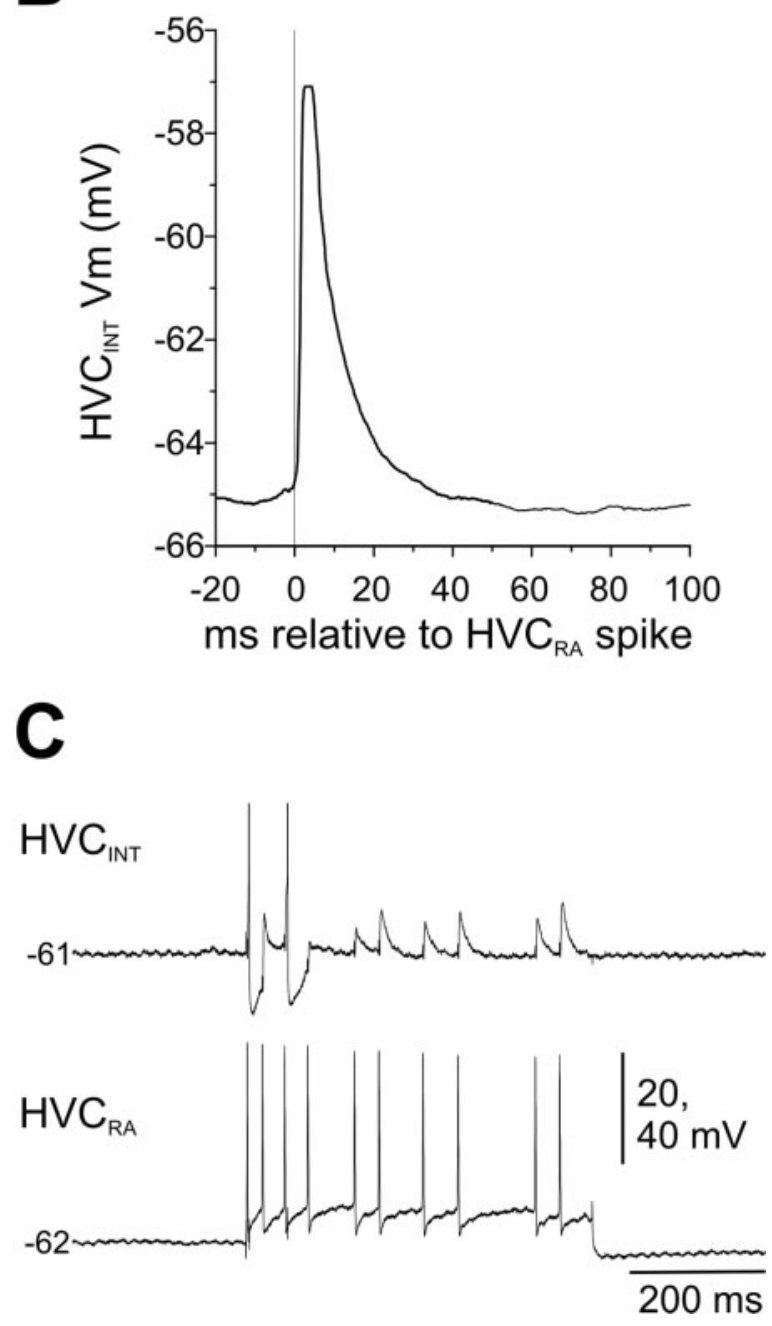

Figure 4. Dual intracellular recordings provide direct evidence of the excitatory synapses that $\mathrm{HVC}_{\mathrm{RA}}$ neurons make with $\mathrm{HVC}_{\mathrm{INT}} \cdot \boldsymbol{A}$, Depolarizing current pulses injected into the $\mathrm{HVC}_{\mathrm{RA}}$ neuron (bottom trace) elicit action potentials, which were followed at short latency by subthreshold (left) and suprathreshold (right) EPSPs in the HVC $\mathrm{INT}_{\mathrm{NT}}$. B, An STA of HVC $\mathrm{INT}_{\mathrm{INT}}$ membrane potential triggered off of the $\mathrm{HVC}_{\mathrm{RA}}$ action potential, from the cell pair shown in $A$. A fast-rising, short-latency-positive STA was detected after the $\mathrm{HVC}_{\mathrm{RA}}$ action potential, consistent with the idea that the $\mathrm{HVC}_{\mathrm{RA}}$ neuron makes an excitatory synapse with the interneuron. $C$, Longer depolarizing currents could evoke irregular spiking in the $\mathrm{HVC}_{\mathrm{RA}}$ neuron (bottom trace), which were paralleled by dEPSPs in the $\mathrm{HVC}_{\mathrm{INT}}$. In this case, note that the last six $\mathrm{HVC}_{\mathrm{RA}}$ spikes occurred in doublets and that the second dPSP was larger than the one immediately preceding it, suggestive of synaptic facilitation. 
A
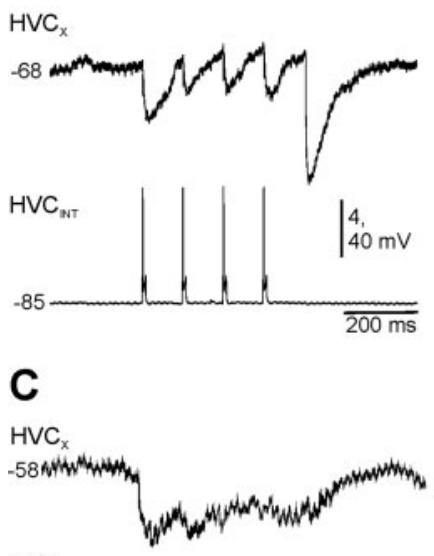

$\mathrm{HVC}_{\mathrm{INT}}$

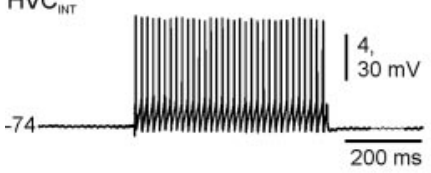

B

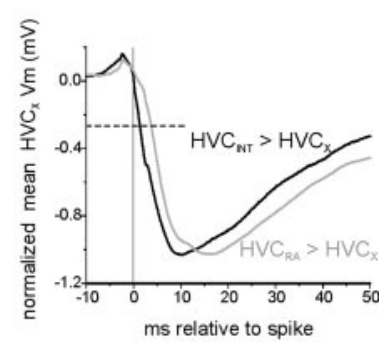

D
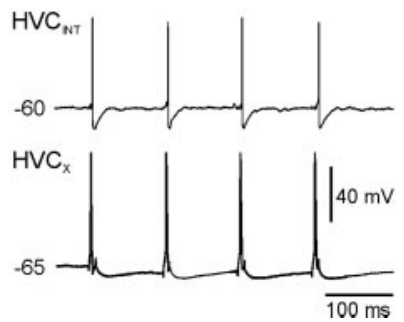

Figure 5. Dual intracellular recordings reveal that $\mathrm{HVC}_{\mathrm{INT}}$ provide short-latency inhibition onto $\mathrm{HVC}_{\mathrm{X}}$ cells. $\boldsymbol{A}$, Raw membrane potential records from a synaptically coupled interneuron (bottom) and $\mathrm{HVC}_{X}$ cell (top). DC-evoked spikes could evoke robust IPSPs in the $\mathrm{HVC}_{X}$ cell; note that a spontaneous IPSP, presumably from another interneuron, occurred after the DC-evoked responses. $\boldsymbol{B}$, The mean STA from all $H V C_{I N T}-H V C_{X}$ cell pairs compared with the mean STA from all $H V C_{R A}-H V C_{X}$ cells pairs, showing the offset in the $25 \%$ rise times (horizontal dashed line) (see Table 2). The overall shapes of the STAs in the different cell pairs were very similar, but the $H V C_{R A}-H V C_{X}$ STA was delayed relative to $H V C_{I N T}-H V C_{X}$ STA, suggesting that $H V C_{R A}$ cells are connected indirectly with $\mathrm{HVC}_{X}$ cells. The STA conventions are as in Figures 2 and 4. $\boldsymbol{C}_{\text {, Higher- }}$ frequency firing in an $\mathrm{HVC}_{\mathrm{INT}_{\mathrm{T}}}$ can drive a sustained hyperpolarization in the $H V C_{X}$ cell. $D, H V C_{X}$ cells in some cases could drive EPSPs in an $\mathrm{HVC}_{\mathrm{INT}}$ cell. DC-evoked firing in the $\mathrm{HVC}_{\mathrm{X}}$ cell (bottom trace) reliably evoked suprathreshold EPSPs in the $H V C_{I N T}$ (top trace). The $H V C_{I N T}$ also evoked IPSPs in the $\mathrm{HVC}_{\mathrm{X}}$ cell (shown in Fig. 9D), indicating that interneurons and $\mathrm{HVC}_{\mathrm{X}}$ cells can form reciprocal synaptic connections.

these responses (i.e., $<1.4 \mathrm{~ms}$ ) supports the view that the fastspiking interneurons we recorded from here provide monosynaptic inhibitory input to $\mathrm{HVC}_{\mathrm{X}}$ cells and thus are plausible cellular intermediaries through which $\mathrm{HVC}_{\mathrm{RA}}$ neurons drive IPSPs in $\mathrm{HVC}_{\mathrm{X}}$ cells. Another feature we noted was that longer action potential trains in the interneuron generated a sustained hyperpolarization in the $\mathrm{HVC}_{\mathrm{X}}$ neuron, reminiscent of song-evoked hyperpolarizations that have been described in $\mathrm{HVC}_{\mathrm{X}}$ cells from in vivo recordings (Fig. $5 C)(n=9$ cases). Therefore, interneurons evoke short-latency IPSPs in $\mathrm{HVC}_{\mathrm{X}}$ cells and are likely to constitute the distal arm of the disynaptic pathway linking $\mathrm{HV}$ $\mathrm{C}_{\mathrm{RA}}$ to $\mathrm{HVC}_{\mathrm{X}}$ cells.

Paired recordings also provided evidence of reciprocal connectivity between interneurons and $\mathrm{HVC}_{\mathrm{X}}$ cells (Figs. 5D) (see Fig. $9 D$, right) ( $n=4$ pairs). In all four reciprocally connected pairs, the $\mathrm{HVC}_{\mathrm{X}}$ neuron action potential evoked a dPSP in the interneuron; in two pairs, these PSPs were demonstrably excitatory (Fig. $5 D$, Table 2) (average peak amplitude, $1.2 \pm 0.3 \mathrm{mV}$; average time to peak, $4.3 \pm 0.4 \mathrm{~ms} ; 25 \%$ rise time, $1.0 \pm 0.6 \mathrm{~ms}$ ). The rapid onset and time to peak of the dPSPs were similar to those recorded in $\mathrm{HVC}_{\mathrm{RA}}-\mathrm{HVC}_{\mathrm{INT}}$ cell pairs (for statistical comparisons, see Table 2). In all of our reciprocally connected $\mathrm{HVC}_{\mathrm{INT}}-\mathrm{HVC}_{\mathrm{X}}$ cell pairs, the interneuron action potential evoked an IPSP in the $\mathrm{HVC}_{\mathrm{X}}$ neuron. Therefore, $\mathrm{HVC}_{\mathrm{X}}$ neurons can form strong excitatory synapses onto interneurons that provide them with reciprocal inhibitory input, suggesting that action

potential activity in $\mathrm{HVC}_{\mathrm{X}}$ neurons, as with $\mathrm{HVC}_{\mathrm{RA}}$ neurons, could be shaped on a spike-by-spike basis by inhibitory feedback.

\section{Pharmacology of $\mathrm{HVC}_{\mathrm{INT}}$-mediated inhibition}

Previous studies showed that IPSPs in HVC neurons are mediated by several different neurotransmitter receptors, including ionotropic $\mathrm{GABA}_{\mathrm{A}}$ receptors and metabotropic GABA and glutamate receptors (Schmidt and Perkel, 1998; Dutar et al., 1999, 2000; Rosen and Mooney, 2003). The relatively fast onset and time to peak of the IPSPs we recorded in $\mathrm{HVC}_{\mathrm{INT}}-\mathrm{HVC}_{\mathrm{X}}$ cell pairs suggested that ionotropic $\mathrm{GABA}_{\mathrm{A}}$ receptors, and not metabotropic receptors, were involved. We tested this idea in several ways. First, we bath applied PTX $(50 \mu \mathrm{M})$, a GABA $\mathrm{A}$ receptor blocker, while recording from synaptically coupled pairs of cells. In two $\mathrm{HVC}_{\mathrm{INT}}-\mathrm{HVC}_{\mathrm{X}}$ pairs and one $\mathrm{HVC}_{\mathrm{RA}}-\mathrm{HVC}_{\mathrm{X}}$ cell pair, spike-evoked IPSPs in the $\mathrm{HVC}_{\mathrm{X}}$ cell were abolished by this treatment, indicating that in both types of connections, ionotropic $\mathrm{GABA}_{\mathrm{A}}$ receptors mediated the IPSP (Fig. 6A, $B$ ) (control, $-1.2 \pm 0.2 \mathrm{mV}$; PTX, $0.0 \pm 0.1 \mathrm{mV} ; n=3 ; p<0.05$; ANOVA). Second, we evoked fast, short-latency IPSPs in $\mathrm{HVC}_{\mathrm{X}}$ cells by antidromically stimulating $\mathrm{HVC}_{\mathrm{RA}}$ neurons and then bath applied PTX $(50 \mu \mathrm{M})$. Treatment with PTX consistently and completely abolished the electrically evoked short-latency IPSP and unmasked a short-latency dPSP (Fig. $7 A$, inset) $(n=12$ cases; control, $-13.7 \pm 0.6 \mathrm{mV}$; PTX, $+4.9 \pm 0.3 \mathrm{mV} ; p=0.000012$ ). Third, paired recording revealed that interneuron-evoked IPSPs in an $\mathrm{HVC}_{\mathrm{X}}$ cell were unaffected by ionotropic glutamate receptor blockers (Fig. 6C), although EPSPs in the interneuron and IPSPs in the $\mathrm{HVC}_{\mathrm{X}}$ cell evoked by antidromic stimulation of $\mathrm{HVC}_{\mathrm{RA}}$ neurons were blocked by this treatment (Fig. 6D) $(n=$ 1). These experiments show that $\mathrm{GABA}_{\mathrm{A}}$ receptors mediate the fast IPSPs evoked in $\mathrm{HVC}_{\mathrm{X}}$ cells by both interneurons and $\mathrm{HV}$ $\mathrm{C}_{\mathrm{RA}}$ cells. These experiments also reveal monosynaptic and/or polysynaptic excitatory pathways from $\mathrm{HVC}_{\mathrm{RA}}$ to $\mathrm{HVC}_{\mathrm{X}}$ cells, which are normally suppressed or otherwise masked by $\mathrm{GABA}_{\mathrm{A}}$ mediated inhibition.

Prolonged blockade of $\mathrm{GABA}_{\mathrm{A}}$ receptors in $\mathrm{HVC}$ also unmasked more complex synaptic interactions between $\mathrm{HVC}_{\mathrm{RA}}$ and $\mathrm{HVC}_{\mathrm{X}}$ cells. Notably, after 15-20 min of PTX application, antidromic stimulation of $\mathrm{HVC}_{\mathrm{RA}}$ neurons evoked larger EPSPs capable of eliciting a high-frequency action potential burst in the $\mathrm{HVC}_{\mathrm{X}}$ neuron (Fig. $6 E$, middle). In several cells $(n=3)$, repetitive bursting followed a single antidromic stimulus (Fig. 7A). PTX treatment also unmasked evidence for slow inhibitory signaling from $\mathrm{HVC}_{\mathrm{RA}}$ to $\mathrm{HVC}_{\mathrm{X}}$ cells. In two cells, a prolonged, multiphasic response was evoked by $\mathrm{HVC}_{\mathrm{RA}}$ stimulation shortly after applying PTX but before the emergence of the dPSP (Fig. 7B, left). In addition, prolonged hyperpolarizations sometimes followed the shorter-latency dEPSPs (Fig. $7 A, B$, right). The shorterlatency EPSPs, as well as associated prolonged hyperpolarizations, were completely abolished by a combination of NBQX and $\mathrm{D}-\mathrm{APV}$, indicating they were mediated in part via monosynaptic and/or polysynaptic pathways involving ionotropic glutamate receptors (Figs. $6 E$, right; $7 A)(n=9$ cases; PTX, $+8.8 \pm 1.7 \mathrm{mV}$; NBQX/D-APV,$-0.1 \pm 0.12 \mathrm{mV} ; p<0.001$; Mann-Whitney $U$ test). In summary, these pharmacological experiments show that fast-spiking interneurons evoke IPSPs in $\mathrm{HVC}_{\mathrm{X}}$ cells via $\mathrm{GABA}_{\mathrm{A}}$ receptors. Furthermore, $\mathrm{HVC}_{\mathrm{RA}}$ neurons drive excitatory and inhibitory responses in $\mathrm{HVC}_{\mathrm{X}}$ neurons via synaptic pathways that involve ionotropic glutamate receptors. 
A

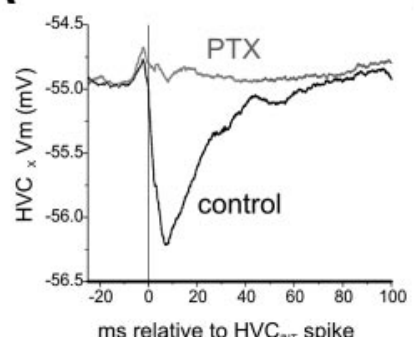

B
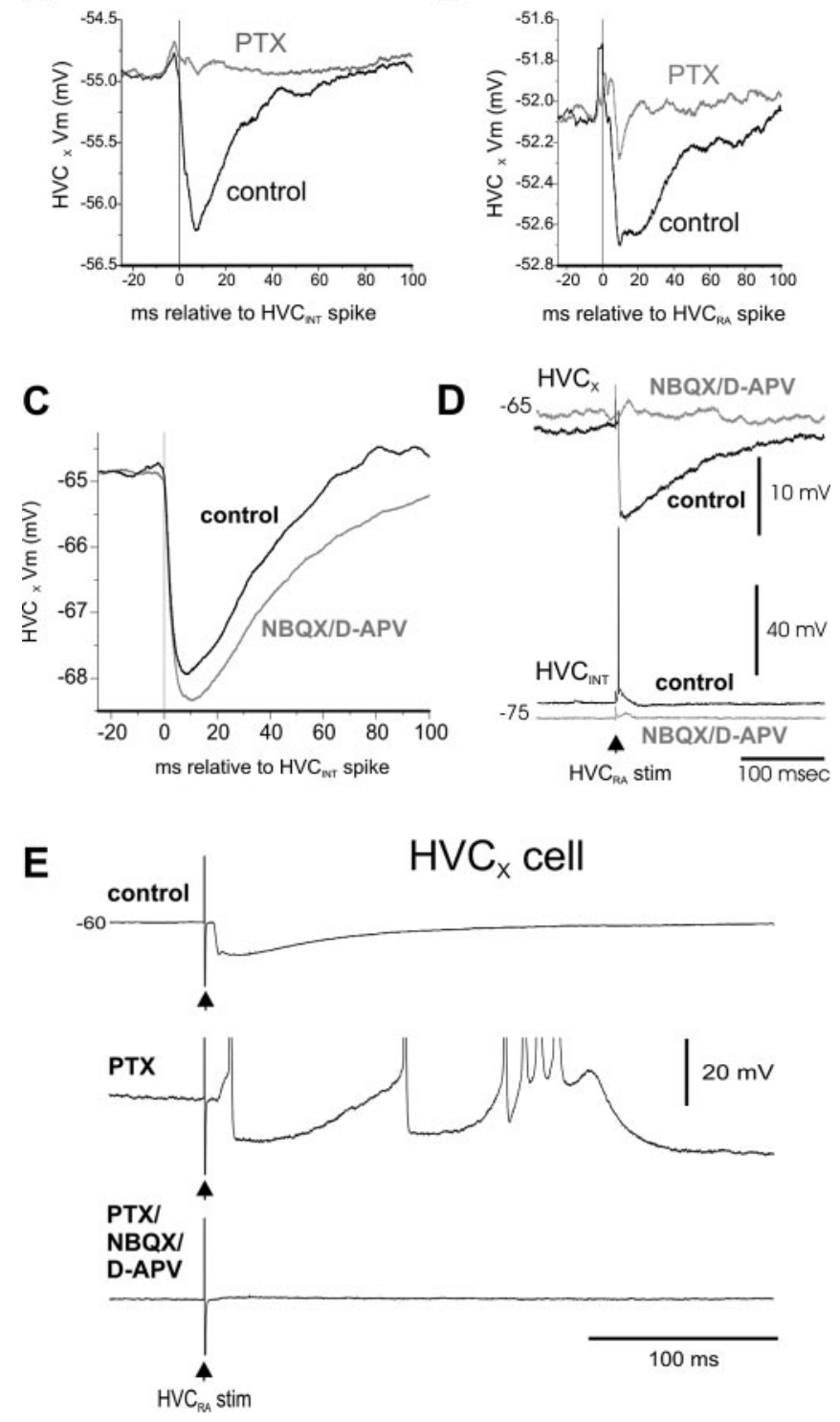

Figure 6. The IPSPs evoked in $\mathrm{HVC}_{X}$ cells by both interneurons and $\mathrm{HVC}_{\mathrm{RA}}$ cells were mediated by $G A B A_{A}$ receptors. $A$, In this interneuron-HVC cell pair, action potentials in the interneuron evoked a hyperpolarizing response in the $H V C_{X}$ cell, indicative of an IPSP (control). Bath application of the GABA $A_{A}$ receptor antagonist PTX blocked the IPSP. $B$, A negative STA of the $H_{V} C_{X}$ membrane potential evoked by action potentials in an $\mathrm{HVC}_{\mathrm{RA}}$ neuron was also blocked by the bath application of PTX. C, An IPSP evoked in an $\mathrm{HVC}_{X}$ cell by DC-evoked action potentials in a simultaneously recorded interneuron did not decrement in the presence of ionotropic glutamate receptor blockers NBQX and D-APV. D, In the same pair of neurons, antidromic stimulation of the $H V C_{R A}$ fiber tract (arrow) evoked an EPSP in the interneuron (bottom; control) and an IPSP in the simultaneously recorded $\mathrm{HVC}_{\mathrm{X}}$ cell (top; control). Subsequent bath application of NBQX/ $D$-APV greatly reduced the excitation onto the interneuron and abolished the IPSP in the HVC cell. Thus, in the presence of compounds that block fast excitatory transmission, inhibition from $H V C_{R A}$ onto $H V C_{X}$ cells is abolished, although inhibition from the interneuron onto the $H V C_{X}$ cell persists. $E$, Antidromic stimulation of the $\mathrm{HV}_{\mathrm{RA}}$ fiber tract was used to evoke an IPSP in an $\mathrm{HVC}_{\mathrm{X}}$ cell (control). Subsequent bath application of PTX abolished the IPSP, unmasking robust EPSPS, resulting in repetitive action potential discharge in the $\mathrm{HVC}_{\mathrm{X}}$ neuron (PTX; middle; 4 spikes in burst; mean burst rate, $111 \mathrm{~Hz}$ ). The subsequent addition of the ionotropic glutamate receptor blockers NBQX and D-APV blocked all synaptic responses in the $\mathrm{HVC}_{\mathrm{X}}$ cell.

Interneurons that evoke IPSPs are PV positive

The interneurons that evoke IPSPs in $\mathrm{HVC}_{\mathrm{X}}$ cells are fast-spiking cells with varicose dendrites (Fig. 1C,D). Previous immunohistochemical studies indicated that fast-spiking HVC interneurons
A
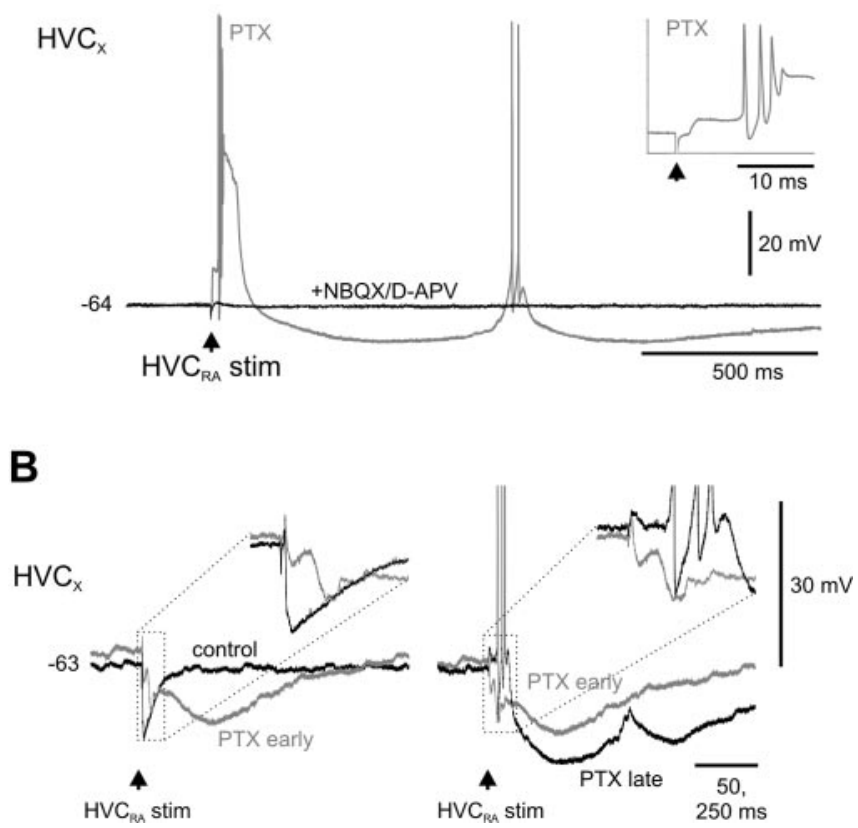

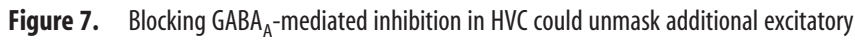
and inhibitory synaptic pathways from $\mathrm{HVC}_{\mathrm{RA}}$ to $\mathrm{HVC}_{\mathrm{X}}$ neurons. $A$, In a PTX-treated brain slice, antidromic stimulation of $\mathrm{HVC}_{\mathrm{RA}}$ neurons could evoke repetitive bursting (early burst: 3 spikes, $200 \mathrm{~Hz}$ mean burst rate; later burst: 2 spikes, $59 \mathrm{~Hz}$ burst rate) and slow hyperpolarizing responses, which were blocked by the bath application of the ionotropic glutamate receptor antagonists NBQX and D-APV. $B$, Before PTX treatment, antidromic stimulation of the $H C_{R A}$ fibers evoked a fast IPSP in an $\mathrm{HVC}_{\mathrm{X}}$ neuron (control); subsequent PTX treatment blocked the early, fast IPSP and unmasked a multiphasic IPSP that included a slow component (PTX early). At later times during the treatment (PTX late), the same stimulation evoked an initial excitatory response, followed by a prolonged, biphasic hyperpolarization. The subthreshold depolarization that occurs during the middle of the slow, biphasic hyperpolarization is believed to be similar to the event associated with the longer-latency bursting behavior in $\boldsymbol{A}$.

with varicose dendrites are PV positive (PV+) (Wild et al., 2005) but did not resolve whether PV+ interneurons are a source of inhibitory input onto HVC PNs. We used anti-PV antibodies and intracellular staining with Neurobiotin to determine whether the interneurons that provided inhibitory input onto $\mathrm{HVC}_{\mathrm{X}}$ cells were $\mathrm{PV}+$. In two $\mathrm{HVC}_{\mathrm{INT}}-\mathrm{HVC}_{\mathrm{X}}$ pairs, morphologically and physiologically identified fast-spiking interneurons that evoked IPSPs in $\mathrm{HVC}_{\mathrm{X}}$ cells were $\mathrm{PV}+$, whereas the corresponding $\mathrm{HVC}_{\mathrm{X}}$ cells were PV negative (PV-) (Fig. 8A). We did note, however, that $\mathrm{HVC}_{\mathrm{X}}$ neurons were sometimes in extremely close apposition to $\mathrm{PV}+$ cell bodies (Fig. $8 B)(n=2$ cases). These results show that $\mathrm{PV}+$ interneurons provide some of the inhibitory input onto HVC PNs that innervate basal ganglia structures in the songbird brain.

\section{Homotypic synaptic interactions}

Paired recordings also revealed synaptic interactions between neurons of the same type. Eleven $\mathrm{HVC}_{\mathrm{X}}$ pairs showed signs of unidirectional inhibitory synaptic coupling, all in the form of spike-evoked IPSPs (individual data not shown; average peak amplitude, $-2.0 \pm 0.4 \mathrm{mV}$; average time to peak, $15.4 \pm 2.7 \mathrm{~ms}$; $25 \%$ rise time, $5.0 \pm 1.7 \mathrm{~ms} ; n=11$ ) (for mean data, see Table 2). These IPSPs were presumably mediated by intervening interneurons, in part because recordings previously described indicated that $\mathrm{HVC}_{\mathrm{X}}$ neurons can make excitatory synapses onto $\mathrm{HVC}_{\mathrm{INT}}$. Furthermore, the mean $25 \%$ rise time of IPSPs evoked in $\mathrm{HVC}_{\mathrm{X}}-$ $\mathrm{HVC}_{\mathrm{X}}$ cell pairs was significantly longer than that of IPSPs re- 
corded in $\mathrm{HVC}_{\mathrm{INT}}-\mathrm{HVC}_{\mathrm{X}}$, but not HV$\mathrm{C}_{\mathrm{RA}}-\mathrm{HVC}_{\mathrm{X}}$, cell pairs (for statistical comparisons, see Table 2). Five $\mathrm{HVC}_{\mathrm{RA}}$ pairs were also recorded: four exhibited unidirectional dEPSPs (Table 2), whereas one showed an IPSP (data not shown). Finally, one synaptically coupled interneuron pair was detected that exhibited a unidirectional IPSP (data not shown) (Table 1). Therefore, inhibitory as well as excitatory connections serve to synaptically link homotypic as well as heterotypic pairs of neurons within HVC.

\section{Divergent and convergent synaptic connections in HVC}

The extensive local axonal network of both PNs and interneurons raises the possibility of divergent and convergent patterns of synaptic connectivity within HVC. We were able to detect both divergent and convergent synaptic connections by recording from one HVC neuron with a fixed electrode and moving a second electrode about the slice to sequentially record from a series of other cells that were either its presynaptic or postsynaptic partner. In four of these sequential paired recordings, the fixed electrode was in an interneuron, whereas the moveable electrode encountered a series of PNs. Three qualitative observations resulted from these recordings. First, a single interneuron can evoke IPSPs in both $\mathrm{HVC}_{\mathrm{RA}}$ and $\mathrm{HVC}_{\mathrm{X}}$ neurons (Fig. 9A). Second, a single interneuron can make divergent inhibitory synapses on several $\mathrm{HVC}_{\mathrm{X}}$ cells (Fig. 9B). Third, a single interneuron can receive convergent input from two or more HV$\mathrm{C}_{\mathrm{RA}}$ neurons (data not shown). In three other sequential paired recordings, the fixed electrode was placed in an $\mathrm{HVC}_{\mathrm{X}}$ neuron, whereas the moveable electrode recorded from $\mathrm{HVC}_{\mathrm{INT}}$ and/or $\mathrm{HVC}_{\mathrm{RA}}$ neurons. These recordings revealed that both $\mathrm{HVC}_{\mathrm{INT}}$ and $\mathrm{HVC}_{\mathrm{RA}}$ neurons can provide inhibitory input onto the same $\mathrm{HVC}_{\mathrm{X}}$ cell (Fig. 9C). Therefore, single interneurons can contact PNs of both types and can receive convergent excitatory input from $\mathrm{HVC}_{\mathrm{RA}}$ neurons.

Interneurons also receive convergent excitatory input from $\mathrm{PNs}$ of different types. We examined interactions between the three cell types by coupling antidromic stimulation of $\mathrm{HVC}_{\mathrm{RA}}$ neurons while using two electrodes to record from $\mathrm{HVC}_{\mathrm{INT}}$ $\mathrm{HVC}_{\mathrm{X}}$ cell pairs. In all six pairs, the $\mathrm{HVC}_{\mathrm{INT}}$ evoked IPSPs in the $\mathrm{HVC}_{\mathrm{X}}$ cell; in two of these pairs, the $\mathrm{HVC}_{\mathrm{X}}$ cell provided reciprocal excitation to the interneuron. In all of these pairs, antidromic activation of the $\mathrm{HVC}_{\mathrm{RA}}$ axon collateral network evoked an EPSP in the $\mathrm{HVC}_{\mathrm{INT}}$ cell and an IPSP in the $\mathrm{HVC}_{\mathrm{X}}$ cell (Fig. 9D). These results show that the two PN types provide convergent excitatory input onto single interneurons, which in turn provide an inhibitory link between the HVC PNs. The various features of the local synaptic organization of HVC revealed in this study are summarized in Figure 10.

\section{Frequency of synaptic connections between different HVC cell types}

We also performed additional paired recordings to provide an estimate both of the frequency of pair types that we encountered using these recording methods and the frequency of synaptic connections that we detected between neurons of given types. A

\section{B}

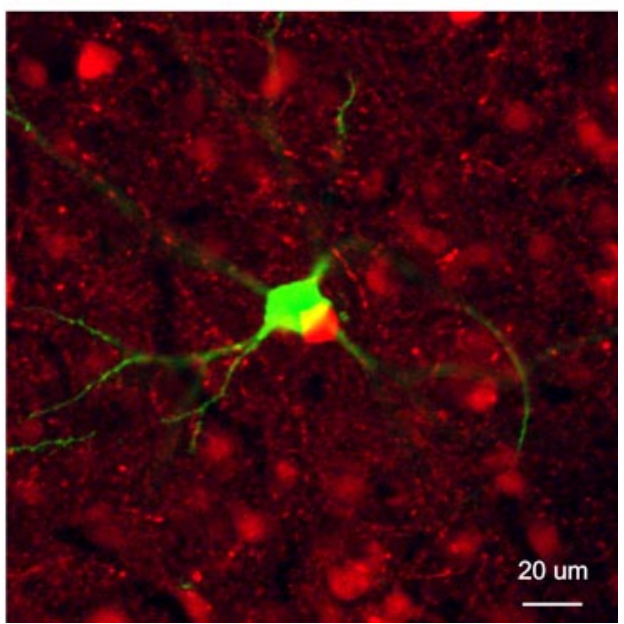

0 um total of 96 pairs was obtained, 18 of which displayed either unidirectional or bidirectional synaptic coupling $(\sim 19 \%$; note that the connected pairs from this sample contributed to the total pool of connected pairs represented in Table 2 and discussed in previous sections of Results) (Table 1). Several features of this sample are notable. First, the vast majority of pairs that we obtained [77 of $96(\sim 80 \%)$ ] contained at least one $\mathrm{HVC}_{\mathrm{X}}$ neuron, likely reflecting the fact that these cells are relatively numerous and large, and typically afford the most stable recordings with the sharp electrode methods used in this study. Second, almost twothirds [61 of $96(63 \%)$ ] of all pairs consisted of $\mathrm{HVC}_{\mathrm{RA}}$ neurons, which despite their small size are highly abundant (Kirn et al., 1991; Wild et al., 2005). Perhaps as a result of these various factors, $\mathrm{HVC}_{\mathrm{RA}}-\mathrm{HVC}_{\mathrm{X}}$ neuron pairs made up almost one-half this sample [46 of $96(\sim 48 \%)$ ]. Finally, in contrast to our overall larger sample of $\mathrm{HVC}_{\mathrm{RA}}$ and $\mathrm{HVC}_{\mathrm{X}}$ neuron pairs, this smaller sample exhibited a higher proportion of $\mathrm{HVC}_{\mathrm{X}}$-to- $\mathrm{HVC}_{\mathrm{RA}}$ synaptic connections [5 of $6(83 \%)$ vs 7 of $29(24 \%)$ ] and included three reciprocally connected cell pairs.

\section{Discussion}

The present study reveals several synaptic features likely to be important to the song-related motor and auditory functions of HVC. First, $\mathrm{HVC}_{\mathrm{RA}}$ neurons excite interneurons, which inhibit $\mathrm{HVC}_{\mathrm{X}}$ neurons, providing a feedforward inhibitory mechanism linking song premotor and basal ganglia projecting pathways emanating from HVC. This feedforward inhibition could help shape motor-related activity transmitted to the AFP and generate cell type-specific patterns of auditory activity. Second, interneurons innervate multiple PNs of both types and thus could coordinate their activity. Finally, HVC contains reciprocally connected PNs and interneurons, similar to other pattern-generating networks.

\section{Feedforward inhibition and excitation from $\mathrm{HVC}_{\mathrm{RA}}$ to HVC $_{X}$ neurons}

These studies show that $\mathrm{HVC}_{\mathrm{X}}$ cells, which innervate basal ganglia structures important to vocal plasticity (Nottebohm et al., 1976, 1982; Bottjer et al., 1984; Scharff and Nottebohm, 1991), 
A
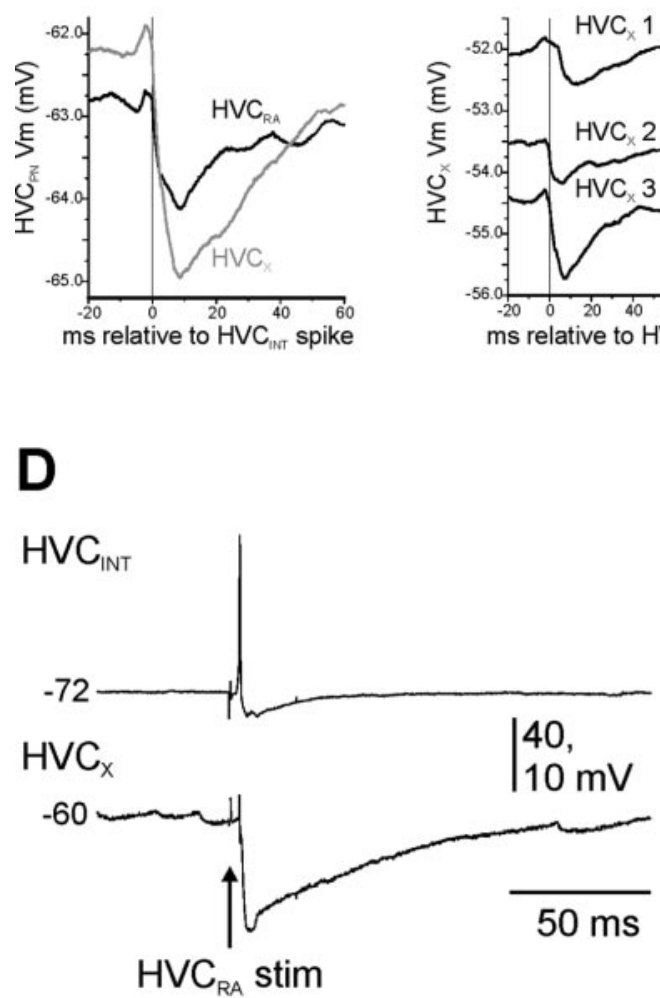

\section{C}
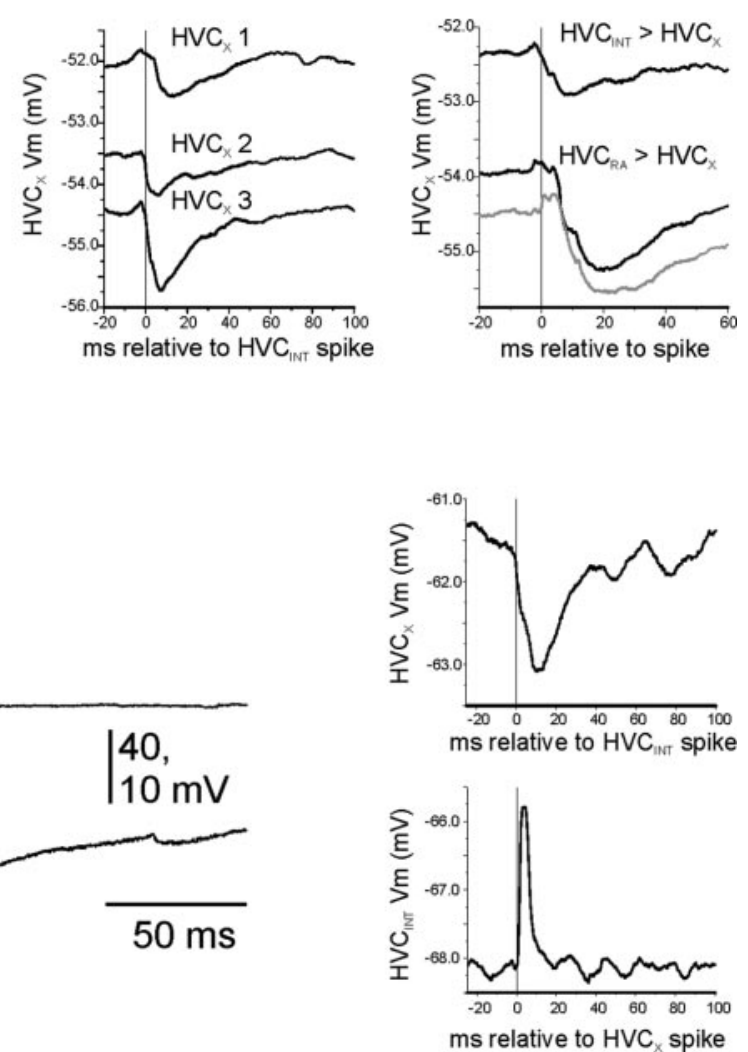

Figure 9. Sequential paired recordings reveal divergent and convergent inhibitory and excitatory synaptic connections in HVC. $A$, Sequential recordings from an $\mathrm{HVC}_{\mathrm{RA}}$ and $\mathrm{HVC}_{\mathrm{x}}$ neuron while maintaining an intracellular recording from an interneuron. The averages of both PN membrane potentials triggered off of the action potentials of the interneuron showed that a single interneuron could evoke IPSPs in both cells. $B$, Sequential recordings from three different $H V C_{x}$ neurons $\left(H V C_{x} 1-3\right)$ show that action potentials in a single interneuron could evoke IPSPs in all three $H_{V} C_{X}$ cells. C, Sequential recordings from an interneuron and two different $H V C_{R A}$ neurons while maintaining a recording from a single $H V C_{X}$ cell show that both $H V C_{R A}$ cells and the interneuron can provide inhibitory input onto the same $H V C_{X}$ cell. $\boldsymbol{D}, A$ reciprocally connected interneuron- $H V C_{X}$ cell pair also receives synaptic input from $\mathrm{HVC}_{\mathrm{RA}}$ axon collaterals. Antidromic stimulation of $\mathrm{HVC}_{\mathrm{RA}}$ axons evokes an EPSP in the interneuron (top) and an IPSP in the HVC $C_{x}$ cell (bottom). Spike-triggered averaging reveals that the interneuron evokes an IPSP in the HVC cell, which in turn could evoke a dPSP in the interneuron. This is the same $H V C_{x}$-interneuron pair shown in Figure $5 D$, in which action potentials in the $H V C_{x}$ cell evoked suprathreshold EPSPs in the interneuron. These recordings show that both $\mathrm{HVC}_{\mathrm{X}}$ and $\mathrm{HVC}_{\mathrm{RA}}$ axon collaterals can excite the same interneuron in HVC.

are inhibited directly by interneurons and indirectly by HVC PNs of both types. The IPSPs from $\mathrm{HVC}_{\mathrm{RA}}$ to $\mathrm{HVC}_{\mathrm{X}}$ cells were most likely mediated via disynaptic, feedforward mechanisms, because: (1) antagonists of ionotropic glutamate receptors blocked all inhibitory synaptic transmission in $\mathrm{HVC}_{\mathrm{X}}$ cells evoked by antidromic stimulation of $\mathrm{HVC}_{\mathrm{RA}}$ fibers; (2) in paired recordings, $\mathrm{GABA}_{\mathrm{A}}$ receptor blockers abolished IPSPs evoked in $\mathrm{HVC}_{\mathrm{X}}$ cells by either $\mathrm{HVC}_{\mathrm{INT}}$ or $\mathrm{HVC}_{\mathrm{RA}}$; (3) $\mathrm{HVC}_{\mathrm{RA}}$ neurons drive fast risetime EPSPs mediated by ionotropic glutamate receptors on $\mathrm{HVC}_{\mathrm{INT}}$ and on their extrinsic targets in the nucleus RA; (4) interneurons drive IPSPs in $\mathrm{HVC}_{\mathrm{X}}$ cells with faster rise times than IPSPs driven in $\mathrm{HVC}_{\mathrm{X}}$ cells by $\mathrm{HVC}_{\mathrm{RA}}$ neurons; and (5) spike doublets in $\mathrm{HVC}_{\mathrm{RA}}$ cells could evoke excitatory synaptic facilitation in interneurons and were sometimes required to trigger IPSPs in $\mathrm{HVC}_{\mathrm{X}}$ cells. Similar disynaptic mechanisms likely underlie IPSPs detected in pairs of $\mathrm{HVC}_{\mathrm{X}}$ cells, because the rise times of these IPSPs were relatively slow, like those in $\mathrm{HVC}_{\mathrm{RA}}-\mathrm{HVC}_{\mathrm{X}}$ cell pairs, and because $\mathrm{HVC}_{\mathrm{X}}$ cells evoke EPSPs in interneurons. Additionally, monosynaptic and polysynaptic excitatory pathways and polysynaptic inhibitory pathways link $\mathrm{HVC}_{\mathrm{RA}}$ to $\mathrm{HVC}_{\mathrm{X}}$ cells but are normally masked by fast inhibition.

\section{Reciprocal connections between HVC} PNs and interneurons

Although a common pattern of synaptic flow was from $\mathrm{HVC}_{\mathrm{RA}}$ to $\mathrm{HVC}_{\mathrm{X}}$ cells, $\mathrm{HVC}_{\mathrm{X}}$ neurons also could evoke depolarizing or hyperpolarizing responses in some $\mathrm{HVC}_{\mathrm{RA}}$ neurons, and reciprocally coupled heterotypic PN pairs were sometimes encountered. Consistent with the idea that $\mathrm{HVC}_{\mathrm{RA}}$ and $\mathrm{HVC}_{\mathrm{X}}$ cells are bidirectionally connected via interneurons, single interneurons could be excited by PNs of both types and also could inhibit multiple PNs of both types. Reciprocal inhibitory interactions between the two PN types may have important implications for the functioning of the HVC in response to song playback and during singing. $\mathrm{HVC}_{\mathrm{RA}}$ and $\mathrm{HVC}_{\mathrm{X}}$ cells alternate in their firing during playback of the BOS (Mooney, 2000), which could be explained if these two types of excitatory neurons were coupled via reciprocal inhibition. More generally, half-center oscillators, wherein two neurons make reciprocally inhibitory connections, can produce highly rhythmic bursts of action potential activity (Cropper and Weiss, 1996; Marder and Bucher, 2001; Cymbalyuk et al., 2002). Although some $\mathrm{HVC}_{\mathrm{RA}}$ and $\mathrm{HVC}_{\mathrm{X}}$ neurons form architecture characteristic of half-center oscillators, the importance of such an arrangement for generating rhythmical activity underlying singing is unclear, because adult song structure remains intact immediately after selective ablation of $\mathrm{HVC}_{\mathrm{X}}$ neurons (Scharff et al., 2000). Therefore, other mechanisms in HVC can generate or transmit patterned song premotor activity when $\mathrm{HVC}_{\mathrm{X}}$ neurons are reduced or absent. One generative mechanism could be reciprocal coupling between excitatory $\mathrm{HVC}_{\mathrm{RA}}$ neurons and fast-spiking inhibitory interneurons. Indeed, reciprocally connected excitatory and inhibitory neurons can form bistable networks, generating either no output or low-frequency rhythms, depending on the amount of excitatory drive applied to the excitatory cells (Borgers and Kopell, 2005).

\section{Functional implications of divergent and convergent synaptic connections}

Sequential paired recordings revealed that interneurons divergently innervate PNs of both types, an arrangement that could synchronize the firing of multiple HVC cells, as occurs in sleeping birds (Rauske et al., 2003). Although synaptically coupled cell pairs recorded here were typically in close proximity (cf. Feldmeyer et al., 1999), intracellular staining showed that interneuron processes are extensive (Fig. 1C) (Katz and Gurney, 1981; Mooney, 2000; Wild et al., 2005), raising the possibility of a more widespread influence on HVC synchrony. Although none of the paired recordings we obtained displayed evidence of electrotonic coupling, gap junctions have been detected in HVC (Gahr and Garcia-Segura, 1996), affording a potential synchronizing influ- 


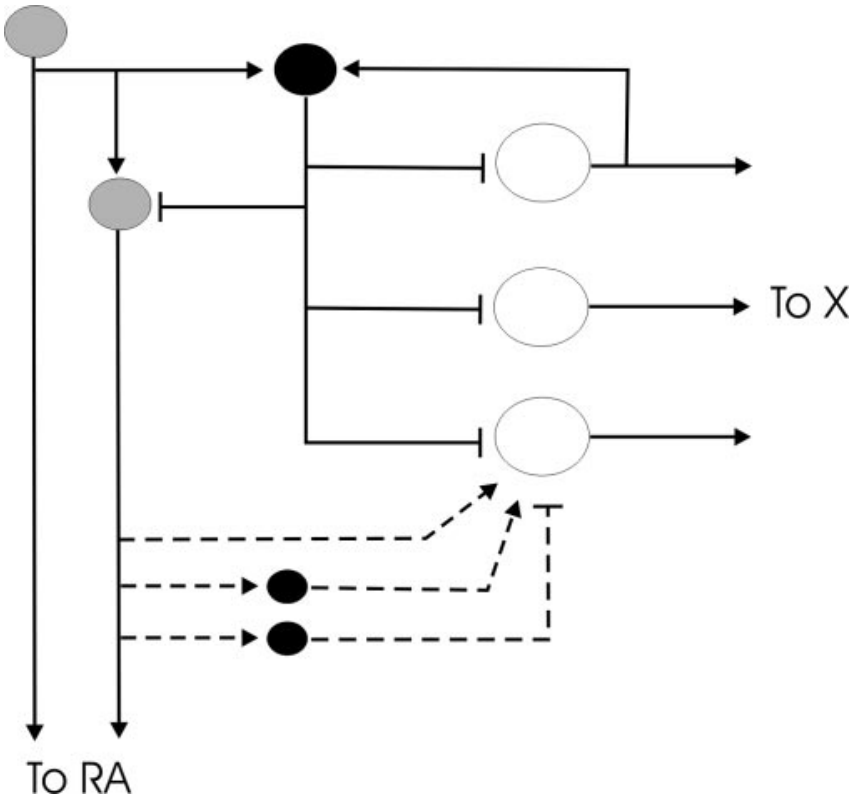

Figure 10. The major synaptic features of the HVC microcircuit revealed in the present study by paired recordings and antidromic stimulation of $\mathrm{HVC}_{\mathrm{RA}}$ neurons are shown. $\mathrm{HVC}_{\mathrm{RA}}$ (gray circles) and $\mathrm{HVC}_{\mathrm{X}}$ (white circles) neurons form excitatory synaptic connections (arrows) on interneurons (black circles), which provide divergent inhibitory input (t-endings) on PNs of both types. Fast excitation is mediated by ionotropic glutamate receptors, whereas fast inhibition is mediated by $G_{A B A_{A}}$ receptors. Additional polysynaptic and possibly monosynaptic excitatory pathways and polysynaptic inhibitory pathways also provide a synaptic linkage from $\mathrm{HVC}_{\mathrm{RA}}$ to $H V C_{x}$ neurons (dashed lines). These monosynaptic and polysynaptic pathways are dependent on ionotropic glutamate receptors, presumably involving direct synapses between $\mathrm{HVC}_{\mathrm{RA}}$ axon collaterals and $\mathrm{HVC}_{\mathrm{x}}$ neurons and intervening synapses between $\mathrm{HVC}_{\mathrm{RA}}$ axon collaterals and other HVC interneurons.

ence on HVC activity in addition to or in conjunction with the interneuron network (Deans et al., 2001; Galarreta and Hestrin, 2002; Long et al., 2004). Divergent patterns of interneuronmediated inhibition have also been invoked to explain $\mathrm{HVC}_{\mathrm{RA}}$ neuronal activity during singing, which is characterized by temporally sparse action potential bursts thought to propagate sequentially through an array of these neurons (Hahnloser et al., 2002). Convergent excitatory input from $\mathrm{HVC}_{\mathrm{RA}}$ neurons onto interneurons, coupled with divergent projections from single interneurons onto multiple $\mathrm{HVC}_{\mathrm{RA}}$ neurons, could form a synaptic substrate for sequence propagation throughout the $\mathrm{HVC}_{\mathrm{RA}}$ neuronal array. An important future goal will be to determine whether single interneurons synapse on multiple $\mathrm{HVC}_{\mathrm{RA}}$ neurons, as shown here for $\mathrm{HVC}_{\mathrm{X}}$ neurons. Furthermore, reciprocal connectivity between single PNs of either type and interneurons, as seen here, could generate negative feedback, limiting spike burst duration and augmenting the temporal sparseness that characterizes HVC PN activity during singing and song playback (Mooney, 2000; Hahnloser et al., 2002). Indeed, simply adding the mean time to peak of $\mathrm{HVC}_{\mathrm{RA}}$ to interneuron and interneuron to $\mathrm{HVC}_{\mathrm{RA}}$ PSPs yields a value of $\sim 15 \mathrm{~ms}$ (Table 2 ). This value is similar to the spike burst duration of $\mathrm{HVC}_{\mathrm{RA}}$ neurons during singing (typically $\sim 6 \mathrm{~ms}$ in vivo) (Hahnloser et al., 2002) and could be regarded as an estimate of the mean upper limit for the time scale over which reciprocal interactions between $\mathrm{HVC}_{\mathrm{RA}}$ and interneurons might occur.

\section{Types of interneuron-mediated inhibition}

Previous in vivo and in vitro studies showed that $\mathrm{HVC}_{\mathrm{X}}$ neurons receive remarkably diverse forms of inhibition, including fast

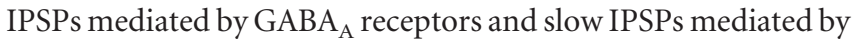
$\mathrm{GABA}_{\mathrm{B}}$ and metabotropic glutamate receptors (Schmidt and Perkel, 1998; Dutar et al., 1999, 2000; Hahnloser et al., 2002; Rosen and Mooney, 2003). This functional diversity may be reflected in part by the diverse calcium-binding protein expression patterns of HVC interneurons, which contain various combinations of PV, calbindin, and calretinin (Wild et al., 2005). The present study shows that at least some fast-spiking interneurons are $\mathrm{PV}+$ and evoke $\mathrm{GABA}_{\mathrm{A}}$ receptor-mediated IPSPs in $\mathrm{HVC}_{\mathrm{X}}$ cells. This result links previous observations that fast-spiking interneurons are PV + (Wild et al., 2005) and that PV + cells coexpress the synthetic enzyme for GABA (Zuschratter et al., 1987). Because PV + neurons evoke fast, $\mathrm{GABA}_{\mathrm{A}}$-mediated IPSPs in $\mathrm{HVC}_{\mathrm{X}}$ cells, they functionally resemble $\mathrm{PV}+$ interneurons in the mammalian cortex, which evoke fast $\mathrm{GABA}_{\mathrm{A}}$-mediated inhibitory synaptic currents in pyramidal neurons (Maccaferri et al., 2000). Interneurons also are the likely source of the slow IPSPs evoked in $\mathrm{HVC}_{\mathrm{X}}$ cells by antidromically stimulating $\mathrm{HVC}_{\mathrm{RA}}$ neurons in the presence of PTX. These slow IPSPs could be blocked by antagonists of ionotropic glutamate receptors, suggesting they arise polysynaptically through $\mathrm{HVC}$ interneurons, rather than monosynaptically via $\mathrm{HVC}_{\mathrm{RA}}$ axon collaterals (i.e., via metabotropic glutamate receptors) (Schmidt and Perkel, 1998; Dutar et al., 1999, 2000). An important future goal will be to further characterize the correspondence between morphological, biochemical and functional properties of different HVC interneuron types.

\section{Relevance to the auditory and motor properties of $\mathrm{HVC}$}

The inhibitory and excitatory linkage from $\mathrm{HVC}_{\mathrm{RA}}$ to $\mathrm{HVC}_{\mathrm{X}}$ cells could have important consequences for the processing of auditory and song motor activity in HVC. Exquisite auditory selectivity for the BOS is a hallmark of HVC neuronal responses in anesthetized songbirds (Margoliash, 1983; Theunissen and Doupe, 1998), and the HVC local circuit is thought to play a role in shaping this selectivity (Lewicki and Konishi, 1995; Lewicki and Arthur, 1996; Mooney, 2000; Rosen and Mooney, 2003; Coleman and Mooney, 2004). Intracellular recordings from urethane anesthetized zebra finches have shown that BOS playback evokes distinct subthreshold responses in the two HVC PNs, including sustained and mostly subthreshold depolarization in $\mathrm{HVC}_{\mathrm{RA}}$ neurons and prolonged hyperpolarizing responses punctuated by phasic excitation in $\mathrm{HVC}_{\mathrm{X}}$ cells (Mooney, 2000). These hyperpolarizing responses help shape the pattern of BOS-evoked firing in $\mathrm{HVC}_{\mathrm{X}}$ cells and likely arise through local inhibition onto $\mathrm{HVC}_{\mathrm{X}}$ cells (Rosen and Mooney, 2003). Indeed, inactivating HVC by local application of GABA unmasks prolonged BOS-evoked depolarizations in $\mathrm{HVC}_{\mathrm{X}}$ cells, pointing to a local source of inhibition (M. Rosen and R. Mooney, unpublished observations). Furthermore, BOS-evoked hyperpolarizations in $\mathrm{HVC}_{\mathrm{X}}$ cells closely correlate with firing in interneurons (Mooney, 2000), and these interneurons appear to be the same type shown here that drive fast IPSPs in $\mathrm{HVC}_{\mathrm{X}}$ cells, because both cells are fast spiking, have varicose dendrites, and are $\mathrm{PV}+$ (Mooney, unpublished observations). However, BOS-evoked hyperpolarizations in $\mathrm{HVC}_{\mathrm{X}}$ cells involve slow G-protein-mediated potassium currents, with only a cryptic contribution from chloride-mediated currents typical of ionotropic $\mathrm{GABA}_{\mathrm{A}}$ receptors (Rosen and Mooney, 2003). Therefore, additional inhibitory pathways normally quiescent in the in vitro preparation must be active during song playback, possibly including the slow inhibitory pathways unmasked by PTX that indirectly link $\mathrm{HVC}_{\mathrm{RA}}$ to $\mathrm{HVC}_{\mathrm{X}}$ cells.

Chronic recordings in singing birds reveal that activity in the AFP is closely locked to the acoustical features of the bird's song 
and persists after deafening, suggesting a motor origin (Hessler and Doupe, 1999; Leonardo, 2002). The inhibitory and excitatory synaptic linkage from $\mathrm{HVC}_{\mathrm{RA}}$ to $\mathrm{HVC}_{\mathrm{X}}$ cells seen here suggests mechanisms by which HVC circuitry could shape and convey song motor activity to the AFP. First, monosynaptic excitation and lagging disynaptic inhibition from $\mathrm{HVC}_{\mathrm{RA}}$ cells could generate tightly correlated phasic excitation in $\mathrm{HVC}_{\mathrm{X}}$ cells (Pouille and Scanziani, 2001), which may enhance signal propagation in the AFP. Second, inhibition can synchronize neuronal firing (Lytton and Sejnowski, 1991; Bush and Sejnowski, 1996) and, in $\mathrm{HVC}_{\mathrm{X}}$ cells, may also trigger burst firing by deinactivation of lowthreshold calcium channels (Kubota and Saito, 1991; Rosen and Mooney, 2003), two features that could facilitate transmission of excitatory signals to the AFP. Third, by analogy to mammalian basal ganglia circuitry (Afifi, 1994; Wichmann and DeLong, 1996; Reiner, 2002), motor-driven inhibition from $\mathrm{HVC}_{\mathrm{RA}}$ onto $\mathrm{HVC}_{\mathrm{X}}$ cells could disinhibit downstream targets in the AFP (Wilson, 1993; Sil'kis, 2002; Nambu, 2004). Indeed, inhibitory synapses in the AFP [i.e., between Area X and the medial nucleus of the dorsolateral thalamus (Luo and Perkel, 2002)] could effect the necessary sign inversion for such disinhibition. Fourth, highfrequency $(>100 \mathrm{~Hz})$ firing in the $\mathrm{HVC}_{\mathrm{RA}}$ neuron sometimes was required to evoke an IPSP in the $\mathrm{HVC}_{\mathrm{X}}$ cell, apparently because of facilitation at the $\mathrm{HVC}_{\mathrm{RA}}$-interneuron synapse. Given the propensity for $\mathrm{HVC}_{\mathrm{RA}}$ neurons to fire in high-frequency bursts during singing (Hahnloser et al., 2002), such facilitation could be integral to shaping premotor activity in $\mathrm{HVC}_{\mathrm{X}}$ neurons and thus modulating AFP song motor activity. Finally, we noted that antidromic stimulation of $\mathrm{HVC}_{\mathrm{RA}}$ neurons evoked an IPSP that was nearly 10 -fold greater in amplitude than unitary IPSPs evoked in $\mathrm{HVC}_{\mathrm{X}}$ neurons by either interneurons or $\mathrm{HVC}_{\mathrm{RA}}$ cells, suggesting that multiple interneurons converge directly onto single $\mathrm{HVC}_{\mathrm{X}}$ cells and that multiple $\mathrm{HVC}_{\mathrm{RA}}$ neurons converge indirectly onto $\mathrm{HVC}_{\mathrm{X}}$ cells. This pattern of convergence in HVC may enable the activity of a larger ensemble of $\mathrm{HVC}_{\mathrm{RA}}$ neurons to be integrated in single cells projecting to the AFP. Because $\mathrm{HVC}_{\mathrm{RA}}$ neurons fire in a temporally sparse manner during singing and song playback (Mooney, 2000; Hahnloser et al., 2002), such synaptic integration may facilitate larger time scale representations of song in the AFP.

\section{References}

Afifi AK (1994) Basal ganglia: functional anatomy and physiology. Part 1. J Child Neurol 9:249-260.

Borgers C, Kopell N (2005) Effects of noisy drive on rhythms in networks of excitatory and inhibitory neurons. Neural Comput, in press.

Bottjer SW, Miesner EA, Arnold AP (1984) Forebrain lesions disrupt development but not maintenance of song in passerine birds. Science 224:901-903

Brainard MS, Doupe AJ (2000) Interruption of a basal ganglia-forebrain circuit prevents plasticity of learned vocalizations. Nature 404:762-766.

Bush P, Sejnowski T (1996) Inhibition synchronizes sparsely connected cortical neurons within and between columns in realistic network models. J Comput Neurosci 3:91-110.

Coleman MJ, Mooney R (2004) Synaptic transformations underlying highly selective auditory representations of learned birdsong. J Neurosci 24:9251-9265.

Cropper EC, Weiss KR (1996) Synaptic mechanisms in invertebrate pattern generation. Curr Opin Neurobiol 6:833-841.

Cymbalyuk GS, Gaudry Q, Masino MA, Calabrese RL (2002) Bursting in leech heart interneurons: cell-autonomous and network-based mechanisms. J Neurosci 22:10580-10592.

Deans MR, Gibson JR, Sellitto C, Connors BW, Paul DL (2001) Synchronous activity of inhibitory networks in neocortex requires electrical synapses containing connexin36. Neuron 31:477-485.

Dutar P, Vu HM, Perkel DJ (1998) Multiple cell types distinguished by physiological, pharmacological, and anatomic properties in nucleus $\mathrm{HVc}$ of the adult zebra finch. J Neurophysiol 80:1828-1838.
Dutar P, Vu HM, Perkel DJ (1999) Pharmacological characterization of an unusual mGluR-evoked neuronal hyperpolarization mediated by activation of GIRK channels. Neuropharmacology 38:467-475.

Dutar P, Petrozzino JJ, Vu HM, Schmidt MF, Perkel DJ (2000) Slow synaptic inhibition mediated by metabotropic glutamate receptor activation of GIRK channels. J Neurophysiol 84:2284-2290.

Feldmeyer D, Egger V, Lubke J, Sakmann B (1999) Reliable synaptic connections between pairs of excitatory layer 4 neurones within a single "barrel" of developing rat somatosensory cortex. J Physiol (Lond) 521:169-190.

Fortune ES, Margoliash D (1995) Parallel pathways and convergence onto $\mathrm{HVc}$ and adjacent neostriatum of adult zebra finches (Taeniopygia guttata). J Comp Neurol 360:413-441.

Foster EF, Bottjer SW (1998) Axonal connections of the high vocal center and surrounding cortical regions in juvenile and adult male zebra finches. J Comp Neurol 397:118-138.

Gahr M, Garcia-Segura LM (1996) Testosterone-dependent increase of gap-junctions in HVC neurons of adult female canaries. Brain Res 712:69-73.

Galarreta M, Hestrin S (2002) Electrical and chemical synapses among parvalbumin fast-spiking GABAergic interneurons in adult mouse neocortex. Proc Natl Acad Sci USA 99:12438-12443.

Hahnloser RH, Kozhevnikov AA, Fee MS (2002) An ultra-sparse code underlies the generation of neural sequences in a songbird. Nature 419:65-70.

Hessler NA, Doupe AJ (1999) Singing-related neural activity in a dorsal forebrain-basal ganglia circuit of adult zebra finches. J Neurosci 19:10461-10481.

Johnson F, Bottjer SW (1993) Induced cell death in a thalamic nucleus during a restricted period of zebra finch vocal development. J Neurosci 13:2452-2462.

Katz LC, Gurney ME (1981) Auditory responses in the zebra finch's motor system for song. Brain Res 221:192-197.

Kirn JR, Alvarez-Buylla A, Nottebohm F (1991) Production and survival of projection neurons in a forebrain vocal center of adult male canaries. J Neurosci 11:1756-1762.

Konishi M (1965) The role of auditory feedback in the control of vocalization in the white-crowned sparrow. Z Tierpsychol 22:770-783.

Kubota M, Saito N (1991) Sodium- and calcium-dependent conductances of neurones in the zebra finch hyperstriatum ventrale pars caudale in vitro. J Physiol (Lond) 440:131-142.

Leonardo A (2002) Neural dynamics underlying complex behavior in a songbird. PhD thesis, California Institute of Technology.

Lewicki MS (1996) Intracellular characterization of song-specific neurons in the zebra finch auditory forebrain. J Neurosci 16:5855-5863.

Lewicki MS, Arthur BJ (1996) Hierarchical organization of auditory temporal context sensitivity. J Neurosci 16:6987-6998.

Lewicki MS, Konishi M (1995) Mechanisms underlying the sensitivity of songbird forebrain neurons to temporal order. Proc Natl Acad Sci USA 92:5582-5586.

Livingston FS, Mooney R (1997) Development of intrinsic and synaptic properties in a forebrain nucleus essential to avian song learning. J Neurosci 17:8997-9009.

Livingston FS, White SA, Mooney R (2000) Slow NMDA-EPSCs at synapses critical for song development are not required for song learning in zebra finches. Nat Neurosci 3:482-488.

Long MA, Landisman CE, Connors BW (2004) Small clusters of electrically coupled neurons generate synchronous rhythms in the thalamic reticular nucleus. J Neurosci 24:341-349.

Luo M, Perkel DJ (2002) Intrinsic and synaptic properties of neurons in an avian thalamic nucleus during song learning. J Neurophysiol 88:1903-1914.

Lytton WW, Sejnowski TJ (1991) Simulations of cortical pyramidal neurons synchronized by inhibitory interneurons. J Neurophysiol 66:1059-1079.

Maccaferri G, Roberts JD, Szucs P, Cottingham CA, Somogyi P (2000) Cell surface domain specific postsynaptic currents evoked by identified GABAergic neurones in rat hippocampus in vitro. J Physiol (Lond) 524:91-116.

Marder E, Bucher D (2001) Central pattern generators and the control of rhythmic movements. Curr Biol 11:R986-R996.

Margoliash D (1983) Acoustic parameters underlying the responses of 
song-specific neurons in the white-crowned sparrow. J Neurosci 3:1039-1057.

Margoliash D, Fortune ES (1992) Temporal and harmonic combinationsensitive neurons in the zebra finch's HVc. J Neurosci 12:4309-4326.

Mooney R (1992) Synaptic basis for developmental plasticity in a birdsong nucleus. J Neurosci 12:2464-2477.

Mooney R (2000) Different subthreshold mechanisms underlie song selectivity in identified $\mathrm{HVc}$ neurons of the zebra finch. J Neurosci 20:5420-5436.

Mooney R, Konishi M (1991) Two distinct inputs to an avian song nucleus activate different glutamate receptor subtypes on individual neurons. Proc Natl Acad Sci USA 88:4075-4079.

Nambu A (2004) A new dynamic model of the cortico-basal ganglia loop. Prog Brain Res 143:461-466.

Nixdorf BE (1989) Ultrastructural analysis of the development and maturation of synapses and subsynaptic structures in the ectostriatum of the zebra finch. J Comp Neurol 290:472-486.

Nottebohm F, Stokes TM, Leonard CM (1976) Central control of song in the canary, Serinus canarius. J Comp Neurol 165:457-486.

Nottebohm F, Kelley DB, Paton JA (1982) Connections of vocal control nuclei in the canary telencephalon. J Comp Neurol 207:344-357.

Perkel DH, Gerstein GL, Moore GP (1967) Neuronal spike trains and stochastic point processes. I. The single spike train. Biophys J 7:391-418.

Pouille F, Scanziani M (2001) Enforcement of temporal fidelity in pyramidal cells by somatic feed-forward inhibition. Science 293:1159-1163.

Prather J, Mooney R (2003) Synaptic coupling of HVC neurons revealed by pairwise recordings. Soc Neurosci Abstr 29:294.11.

Price PH (1979) Developmental determinants of structure in zebra finch song. J Comp Physiol Psychol 93:260-277.

Rauske PL, Shea SD, Margoliash D (2003) State and neuronal classdependent reconfiguration in the avian song system. J Neurophysiol 89:1688-1701.

Reiner A (2002) Functional circuitry of the avian basal ganglia: implications for basal ganglia organization in stem amniotes. Brain Res Bull 57:513-528.
Rosen MJ, Mooney R (2003) Inhibitory and excitatory mechanisms underlying auditory responses to learned vocalizations in the songbird nucleus HVC. Neuron 39:177-194.

Scharff C, Nottebohm F (1991) A comparative study of the behavioral deficits following lesions of various parts of the zebra finch song system: implications for vocal learning. J Neurosci 11:2896-2913.

Scharff C, Kirn JR, Grossman M, Macklis JD, Nottebohm F (2000) Targeted neuronal death affects neuronal replacement and vocal behavior in adult songbirds. Neuron 25:481-492.

Schmidt MF, Perkel DJ (1998) Slow synaptic inhibition in nucleus HVc of the adult zebra finch. J Neurosci 18:895-904.

Selverston AI, Moulins M (1985) Oscillatory neural networks. Annu Rev Physiol 47:29-48.

Sil'kis IG (2002) A possible mechanism for the dopamine-evoked synergistic disinhibition of thalamic neurons via the "direct" and "indirect" pathways in the basal ganglia. Neurosci Behav Physiol 32:205-212.

Theunissen FE, Doupe AJ (1998) Temporal and spectral sensitivity of complex auditory neurons in the nucleus HVc of male zebra finches. J Neurosci 18:3786-3802.

Troyer TW, Doupe AJ (2000) An associational model of birdsong sensorimotor learning I. Efference copy and the learning of song syllables. J Neurophysiol 84:1204-1223.

White SA, Livingston FS, Mooney R (1999) Androgens modulate NMDA receptor-mediated EPSCs in the zebra finch song system. J Neurophysiol 82:2221-2234.

Wichmann T, DeLong MR (1996) Functional and pathophysiological models of the basal ganglia. Curr Opin Neurobiol 6:751-758.

Wild JM, Williams MN, Howie GJ, Mooney R (2005) Calcium binding proteins define interneurons in HVC of the zebra finch (Taeniopygia guttata). J Comp Neurol 483:76-90.

Wilson CJ (1993) The generation of natural firing patterns in neostriatal neurons. Prog Brain Res 99:277-297.

Zuschratter W, Braun S, Scheich H (1987) Co-localization of parvalbumin, calbindin and GABA in avian vocal motor system. Neuroscience [Suppl] 22:S114. 